\title{
Diagenetic barium cycling in Black Sea sediments - A case study for anoxic marine environments
}

\author{
Susann Henkel ${ }^{\mathrm{a}, *}$, José M. Mogollón ${ }^{\mathrm{a}}$, Kerstin Nöthen ${ }^{\mathrm{a}}$, Christine Franke ${ }^{\mathrm{b}}$, \\ Kara Bogus $^{c}$, Eric Robin ${ }^{\mathrm{d}}$, André Bahr ${ }^{\mathrm{e}}$, Martin Blumenberg ${ }^{\mathrm{f}}$, Thomas Pape ${ }^{\mathrm{g}}$, \\ Richard Seifert $^{\text {h }}$, Christian März ${ }^{i}$, Gert J. de Lange ${ }^{j}$, Sabine Kasten ${ }^{\text {a }}$ \\ a Alfred Wegener Institute for Polar and Marine Research, Am Handelshafen 12, 27570 Bremerhaven, Germany \\ ${ }^{\mathrm{b}}$ Centre des Géosciences, Mines ParisTech, 35, rue Saint Honoré, 77305 Fontainebleau Cedex, France \\ ${ }^{\mathrm{c}}$ Department of Geosciences, University of Bremen, Klagenfurter Str., 28359 Bremen, Germany \\ ${ }^{\mathrm{d}}$ Laboratoire des Sciences du Climat et de l'Environnement, (CEA/CNRS/UVSQ), Avenue de la Terrasse, Bâtiment 12, \\ 91198 Gif-sur-Yvette Cedex, France \\ ${ }^{\mathrm{e}}$ Institute of Geoscience, Goethe-University Frankfurt, Altenhöferallee 1, 60438 Frankfurt am Main, Germany \\ ${ }^{\mathrm{f}}$ Geoscience Center, Geobiology Group, Georg-August-University Göttingen, Goldschmidtstr. 3, 37077 Göttingen, Germany \\ ${ }^{\mathrm{g}}$ MARUM - Center for Marine Environmental Sciences and Department of Geosciences, University of Bremen, Klagenfurter Str., \\ P.O. Box 330440, D-28334 Bremen, Germany \\ ${ }^{\mathrm{h}}$ Institute of Biogeochemistry and Marine Chemistry, University of Hamburg, Bundesstr. 55, 20146 Hamburg, Germany \\ ${ }^{\mathrm{i}}$ School of Civil Engineering and Geosciences (CEG), Newcastle University, Newcastle upon Tyne NE1 7RU, United Kingdom \\ ${ }^{j}$ Department of Earth Sciences - Geochemistry, Utrecht University, P.O. Box 80.021, 3508 TA Utrecht, The Netherlands
}

Received 23 December 2010; accepted in revised form 6 April 2012; available online 16 April 2012

\begin{abstract}
High-resolution sedimentary records of major and minor elements ( $\mathrm{Al}, \mathrm{Ba}, \mathrm{Ca}, \mathrm{Sr}, \mathrm{Ti}$ ), total organic carbon (TOC), and profiles of pore water constituents $\left(\mathrm{SO}_{4}^{2-}, \mathrm{CH}_{4}, \mathrm{Ca}^{2+}, \mathrm{Ba}^{2+}, \mathrm{Mg}^{2+}\right.$, alkalinity) were obtained for two gravity cores (core 755 , $501 \mathrm{~m}$ water depth and core 214, $1686 \mathrm{~m}$ water depth) from the northwestern Black Sea. The records were examined in order to gain insight into the cycling of $\mathrm{Ba}$ in anoxic marine sediments characterized by a shallow sulfate-methane transition (SMT) as well as the applicability of barite as a primary productivity proxy in such a setting. The Ba records are strongly overprinted by diagenetic barite $\left(\mathrm{BaSO}_{4}\right)$ precipitation and remobilization; authigenic $\mathrm{Ba}$ enrichments were found at both sites at and slightly above the current SMT. Transport reaction modeling was applied to simulate the migration of the SMT during the changing geochemical conditions after the Holocene seawater intrusion into the Black Sea. Based on this, sediment intervals affected by diagenetic $\mathrm{Ba}$ redistribution were identified. Results reveal that the intense overprint of $\mathrm{Ba}$ and $\mathrm{Ba} \mathrm{x}_{\mathrm{xs}}(\mathrm{Ba}$ excess above detrital average) strongly limits its correlation to primary productivity. These findings have implications for other modern and ancient anoxic basins, such as sections covering the Oceanic Anoxic Events which Ba is frequently used as a primary productivity indicator. Our study also demonstrates the limitations concerning the use of $\mathrm{Ba}_{\mathrm{xs}}$ as a tracer for downward migrations of the SMT: due to high sedimentation rates at the investigated sites, diagenetic barite fronts are buried below the SMT within a relatively short period. Thus, 'relict' barite fronts would only be preserved for a few thousands of years, if at all.
\end{abstract}

(C) 2012 Elsevier Ltd. All rights reserved.

\footnotetext{
* Corresponding author. Current address: Institute of Geology and Mineralogy, Zülpicher Str. 49a, 50674 Cologne, Germany.

E-mail address: susann.henkel@uni-koeln.de (S. Henkel).
} 


\section{INTRODUCTION}

Biogenic barite $\left(\mathrm{BaSO}_{4}\right)$ and excess $\mathrm{Ba}\left(\mathrm{Ba}_{\mathrm{xs}}\right.$, nonterrigenous) are frequently used to reconstruct marine primary productivity because their flux and accumulation rates relate to the flux of total organic carbon (e.g., Goldberg and Arrhenius, 1958; Chow and Goldberg, 1960; Dymond et al., 1992; François et al., 1995; Dymond and Collier, 1996; Kasten et al., 2001; Paytan and Griffith, 2007). Biogenic barite records have been generated across several past intervals including times of hypoxia/anoxia and enhanced burial of organic carbon, such as the Cretaceous Oceanic Anoxic Events, OAEs (e.g., Scopelliti et al., 2004; Bakk, 2007). Barite is highly refractory under oxic conditions, but under anoxic conditions early diagenetic barite dissolution and re-precipitation (Eq. (1)) may limit its ability to act as a proxy for marine primary productivity (e.g., von Breymann et al., 1992; Torres et al., 1996):

$\mathrm{BaSO}_{4} \leftrightarrow \mathrm{Ba}^{2+}+\mathrm{SO}_{4}^{2-}$

Organic matter plays a determinant role in sedimentary redox geochemistry (e.g., Froelich et al., 1979). In organicrich, anoxic sediments, organoclastic sulfate reduction (Eq. (2)) directly consumes sulfate in the presence of organic matter (chemically represented as carbohydrate, $\mathrm{CH}_{2} \mathrm{O}$ ):

$\mathrm{CH}_{2} \mathrm{O}+0.5 \mathrm{SO}_{4}^{2-} \rightarrow \mathrm{HCO}_{3}^{-}+0.5 \mathrm{H}_{2} \mathrm{~S}$

Once sulfate is consumed to near depletion, methanogenesis takes over as the dominant pathway for organic matter degradation (Eq. (3)).

$\mathrm{CH}_{2} \mathrm{O} \rightarrow 0.5 \mathrm{CO}_{2}+0.5 \mathrm{CH}_{4}$

Through advection and diffusion, methane migrates upwards where it meets sulfate in the zone called sulfate-methane transition (SMT). Here, methane and sulfate are concomitantly consumed through a process termed anaerobic oxidation of methane (AOM, e.g., Barnes and Goldberg, 1976; Reeburgh, 1976):

$\mathrm{CH}_{4}+\mathrm{SO}_{4}^{2-} \rightarrow \mathrm{HCO}_{3}^{-}+\mathrm{HS}^{-}+\mathrm{H}_{2} \mathrm{O}$

The SMT represents an important redox boundary with respect to the barium cycle. Above the SMT, barite is stable due to the presence of sulfate. Below the SMT, however, the absence of sulfate may lead to barite dissolution. Furthermore, dissolved $\mathrm{Ba}^{2+}$ may diffuse upward from the deeper anoxic sediments and reprecipitate as authigenic barite at the transition to the sulfate-bearing zone (e.g., Brumsack, 1986; van Os et al., 1991; von Breymann et al., 1992; Torres et al., 1996; Pfeifer et al., 2001; Riedinger et al., 2006; Snyder et al., 2007).

Changes in the sulfate and methane geochemistry lead to a migration of the SMT relative to the sediment surface, and thus to a transient/non-steady state behavior of the pore water system (Kasten et al., 2003). Authigenic barite fronts/enrichments are preserved when the SMT moves at a faster downward rate compared to sediment accumulation, and can therefore potentially be used to trace such shifts (Dickens, 2001). Prominent barite enrichments distributed over several hundreds of meters above deeply buried black shales at the Demerara Rise (Ocean Drilling
Program Leg 207) were, for example, shown to trace the movement of the SMT in response to changing sedimentation rates, increasing sulfate concentrations, and a decrease in methanogenesis within the black shale over time (Arndt et al., 2006, 2009). In this study, we assess an ocean basin where the water column geochemistry changes from oxic to anoxic. Increasing anoxic conditions may limit the downward movement of the SMT. Thus, early diagenesis has the potential to considerably affect the barium cycle. We address the issue by examining two sediment cores from the Black Sea, a marine system that is considered to represent a modern analogue to ocean basins during the OAEs.

In this study, we assess the formation and redistribution mechanisms of solid $\mathrm{Ba}$ in these anoxic sediments by compiling pore water and solid phase data. In order to identify the sediment intervals potentially affected by a post-depositional overprint of solid phase $\mathrm{Ba}$, we applied a numerical transport/reaction model and simulated the movement of the SMT in response to the changing geochemical conditions after the Holocene flooding of the Black Sea.

\section{GEOLOGICAL AND GEOCHEMICAL SETTING OF THE STUDY AREA}

The Black Sea has a surface area of $423,000 \mathrm{~km}^{2}$ and a maximum water depth of $2200 \mathrm{~m}$ (Ross and Degens, 1974). The Bosporus Strait, with a sill depth presently $35 \mathrm{~m}$ below sea level, represents the only connection between the Black Sea and the Mediterranean Sea. Changes in sea level thus strongly affect the amount of seawater entering the Black Sea. After the last glacial period, the Black Sea was flooded by saline waters and transformed from an oxygenated freshwater lake to a well-stratified marine basin with anoxic conditions below $\sim 150 \mathrm{~m}$ water depth (e.g., Degens and Ross, 1972; Hay et al., 1991; Jones and Gagnon, 1994). At present, saline waters $\left(T>8.5^{\circ} \mathrm{C}\right.$, salinity $>21 \%$ ) characterize the deep water mass (Özsoy and Ünlüata, 1997).

The environmental and geochemical/redox variations are well documented in the sedimentary record. From the late Pleistocene to the Holocene, the typical Black Sea succession comprises three major units: Unit III (older than $\sim 7.5$ kyr before present; BP) consists of lacustrine deposits formed below a well-oxygenated water column; Unit II $(\sim 7.5-3.5 \mathrm{kyr} \mathrm{BP})$ is of marine origin and shows total organic carbon (TOC) contents of $1-20 \mathrm{wt} . \%$, reflecting a permanently stratified, mainly anoxic water column; Unit I ( $\sim 3.5 \mathrm{kyr}$ to present) is represented by finely laminated calcareous ooze with 1-10 wt.\% TOC that was deposited after the invasion of coccolithophores (Ross and Degens, 1974; Hay et al., 1991; Arthur et al., 1994; Arthur and Dean, 1998; Pape et al., 2010).

The temporal development of the Holocene seawater intrusion into the Black Sea is subject to debate (e.g., Ross et al., 1970; Deuser, 1972; Ross and Degens, 1974; Ryan et al., 1997; Ballard et al., 2000; Major et al., 2002; Bahr et al., 2008; Soulet et al., 2010). Most recent studies (based on $\mathrm{Sr} / \mathrm{Ca}$ ratios, stable oxygen and strontium isotopes of carbonate shells) indicate that the seawater intrusion started 9.5-9.3 kyr BP (Bahr et al., 2006; Major et al., 
2006; Bahr et al., 2008). Stable oxygen data from ostracod valves indicate that the equilibrium of the Black Sea and global sea level was reached $\sim 100 \mathrm{yr}$ after the first seawater influx (Bahr et al., 2008). Simulations of trace metal cycling, however, suggest a progressive/slow increase in salinity after the initial seawater intrusion (Lüschen, 2004). Studies on salinity changes over the course of the intrusion are scarce and often limited to changes in the biotic assemblages, which reflect the conditions in the oxic surface waters (e.g., Wall and Dale, 1974; Ryan et al., 1997; Marret et al., 2009). Very recently, however, it was concluded from $\delta^{18} \mathrm{O}$ pore water profiles that modern Black Sea hydrologic conditions were not reached until $\sim 2 \mathrm{kyr} \mathrm{BP}$, and that salinity had gradually increased over $7 \mathrm{kyr}$ (Soulet et al., 2010). Besides the postglacial establishment of anoxia, the Black Sea water column is characterized by its exceptionally high dissolved $\mathrm{Ba}^{2+}$ concentrations ( $\sim 450 \mathrm{nM}$ in the deep water) and oversaturation with respect to pure barite by at least a factor of two (Falkner et al., 1993).

Only a few datasets are available on sedimentary Ba concentrations in the Black Sea (Brumsack, 1989; Lüschen, 2004; Baturin, 2011). However, $\mathrm{Ba}$ is not discussed in detail in these studies and information on dissolved $\mathrm{Ba}^{2+}$ is not provided. Calvert (1990) presented solid phase Ba data for two gravity cores from the central and eastern Black Sea and inferred that $\mathrm{Ba} / \mathrm{Al}$ maxima associated with TOC enrichments reflect an "increased fertility of the Black Sea".

\section{MATERIALS AND METHODS}

\subsection{Sampling procedure}

The gravity cores 755 and 214 were retrieved from the northwestern Black Sea continental margin during RV Poseidon cruise P317/2 (September 2004) and RV Meteor cruise M72/1 (February 2007), respectively (Fig. 1). Core $755\left(44^{\circ} 44.13^{\prime} \mathrm{N}, 32^{\circ} 01.70^{\prime} \mathrm{E} ; 574 \mathrm{~cm}\right.$ length $)$ was recovered from $501 \mathrm{~m}$ below sea level (mbsl) and core 214 $\left(44^{\circ} 24.10^{\prime} \mathrm{N} ; 32^{\circ} 51.27^{\prime} \mathrm{E} ; 412 \mathrm{~cm}\right.$ length) from $1686 \mathrm{mbsl}$.

Immediately after recovery, the cores were cut into $1 \mathrm{~m}$ segments. For methane analyses, samples were taken according to Schulz (2006). While segmenting the core, $5 \mathrm{ml}$ of sediment were sampled from the lower end of each segment using syringes with cut tips, and transferred into headspace vials containing a saturated $\mathrm{NaCl}$-solution. The vials were closed gas-tight, shaken, and stored at $4{ }^{\circ} \mathrm{C}$ until analysis. Additional sampling for methane was carried out through small openings cut into the core liner at $25 \mathrm{~cm}$ depth intervals. Pore water samples from core 755 were obtained using the squeezer method in an argon-flooded glove box (Reeburgh, 1967; Schlüter, 1990; De Lange, 1992), while for core 214 the rhizon technique (pore size $0.1 \mu \mathrm{m}$ ) was used (Seeberg-Elverfeldt et al., 2005). Pore water extraction was completed within a couple of hours after core collection. Subsamples were taken for alkalinity (only for core 755 ), $\mathrm{Fe}^{2+}$, hydrogen sulfide (fixed as $\mathrm{ZnS}$ ), sulfate, and cation analysis. All pore water samples as well as the cores were stored at $4{ }^{\circ} \mathrm{C}$.

Solid phase samples were taken in $2 \mathrm{~cm}$-intervals using plastic syringes with cut tips (core 755) or a ceramic knife (core 214). The sediment samples were frozen immediately, freeze-dried, and homogenized in an agate mortar before analysis.

\subsection{Pore water analyses}

Alkalinity was determined onboard by titration with $\mathrm{HCl}$ following the procedure of Grasshoff et al. (1983). Methane was measured onboard either using a Thermo Trace gas chromatograph pulse-discharge detector as previously described by Blumenberg et al. (2007) (core 755), or by applying a Carlo Erba gas chromatograph equipped with a flame ionization detector as described by Seifert et al. (1999) (core 214). The values were corrected for a sediment porosity of 0.8 . The methane concentrations reported here are affected by degassing during and after core retrieval due to loss of hydrostatic pressure (e.g., Dickens et al., 1997; Paull et al., 2000) and therefore represent minimum values. Site 214 lies within the methane hydrate stability field, located below $\sim 720 \mathrm{~m}$ water depth in the Black Sea (Bohrmann et al., 2003; Naudts et al., 2006; Pape et al., 2010). Remarkable degassing features in the sediment, probably due to gas hydrate destabilization induced by pressure release, were observed in this core at about $260 \mathrm{cmbsf}$. Stable carbon isotope signatures of methane in core 214 were analyzed at the University of Hamburg as described by Seifert et al. (2006).

Sulfide, sulfate, and cation analyses were performed at the University of Bremen and at the Alfred Wegener Institute for Polar and Marine Research (AWI). Hydrogen sulfide was analyzed photometrically using the methylene blue method (Cline, 1969). For sulfate concentrations, aliquots of diluted samples were injected into an ion chromatograph (Metrohm IC Net 2.3) with a Metrosep A Supp 5 anion column. The consistency of the measurements was checked by analyzing replicates of a sulfate standard and standard seawater (International Association for the Physical Sciences of the Ocean) after every 15 th sample. In core 214 , sulfate was detected below the SMT (at 155-275 cmbsf). These data need to be considered with caution because they are possibly affected by sulfide oxidation during storage. Cation concentrations $\left(\mathrm{Ba}^{2+}, \mathrm{Ca}^{2+}, \mathrm{Mg}^{2+}\right)$ in the pore water samples were measured by inductively coupled plasma optical emission spectrometry (ICP-OES; Perkin Elmer Optima 3300).

The computer program PHREEQC 2.15 (Parkhurst and Appelo, 1999) was used to calculate the saturation index for $\mathrm{BaSO}_{4}: S I=\log \left(I A P / K_{s p}\right)$, where $I A P$ denotes the Ion Activity Product and $K_{s p}$ the solubility product constant of barite $\left(\log K_{s p}=-10.28\right.$ at a temperature of $8.5^{\circ} \mathrm{C}$; based on molar concentrations). The $S I$ was converted into the saturation state $\left(\Omega=I A P / K_{s p}\right)$ indicating super-saturation at $\Omega>1$.

\subsection{Solid phase analyses}

\subsubsection{Major and minor elements}

About $50 \mathrm{mg}$ of bulk sediment were dissolved in a microwave system (MLS ETHOS 1600 and MEGA II for core 755, CEM MARS for core 214) using a concentrated acid mixture of $\mathrm{HNO}_{3}, \mathrm{HCl}$, and $\mathrm{HF}$ (3:2:2 for core 755, 


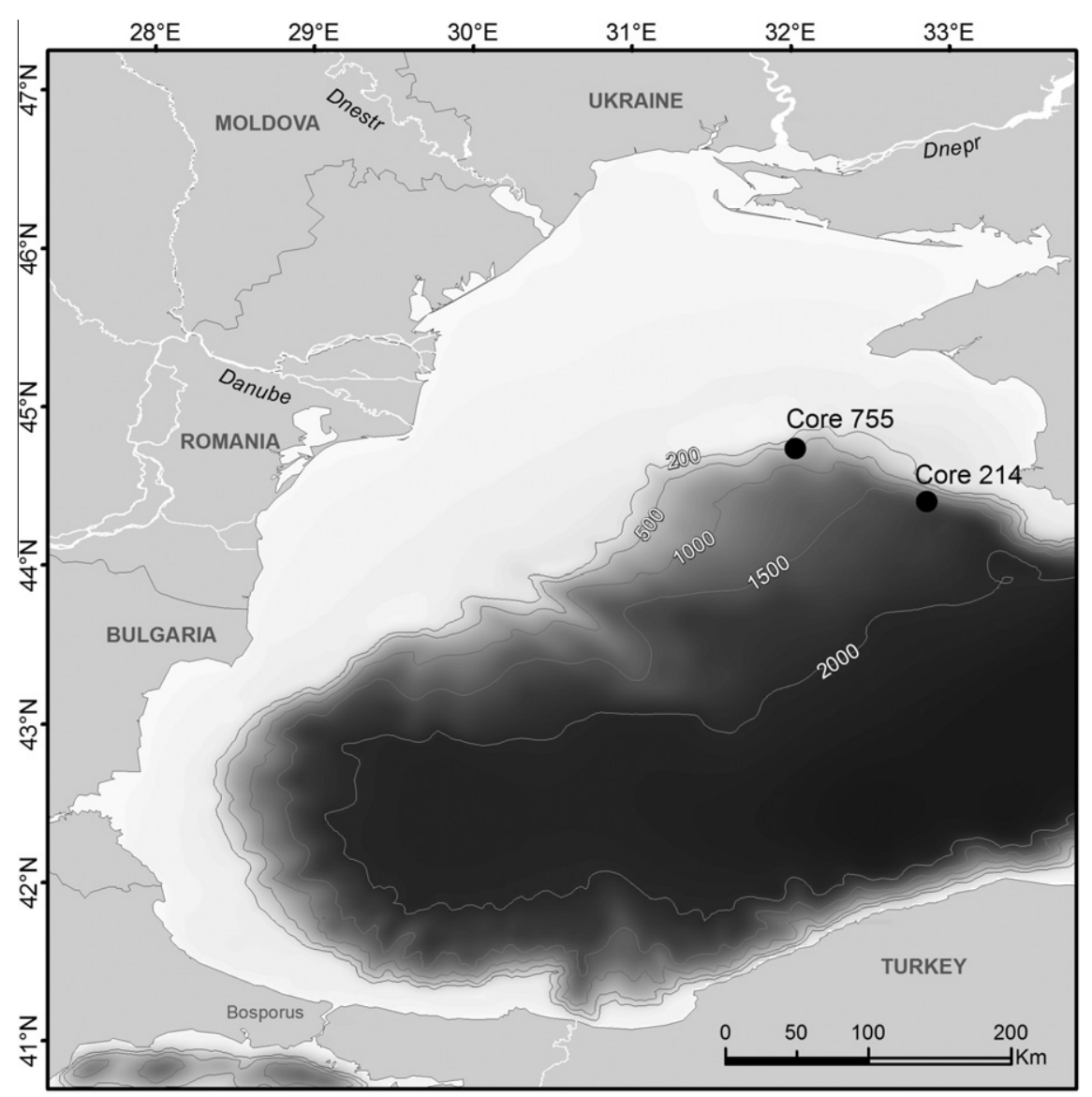

Fig. 1. Bathymetric map [m] of the western Black Sea basin showing the positions of gravity cores 214 and 755 at $501 \mathrm{mbsl}$ and $1686 \mathrm{mbsl}$, respectively.

6:4:1 for core 214). After full evaporation of the solution, the residue was re-dissolved in a $\mathrm{HNO}_{3}$ solution. No inter-calibration was performed for the different labs, but standards were used to check the accuracy and precision of the data. For core 755, the standard reference sediment USGS-MAG-1 (Gladney and Roelandts, 1988) and the two in-house marine sediment standards MAX and CAMAX (Gleiß, 2005) were processed every 10 samples. For core 214, the standard reference material SRM2702 (National Institute of Standards \& Technology) was used. Elements present in the digestion solution of core 755 were measured by ICP-OES (Perkin-Elmer Optima 3300) at the University of Bremen. The recoveries were $101.0 \pm 2.8 \%$ for $\mathrm{Al}, 99.0 \pm 3.8 \%$ for $\mathrm{Ba}, 102.4 \pm 4.2 \%$ for $\mathrm{Ca}$, $98.5 \pm 4.3 \%$ for $\mathrm{Sr}$, and $103.9 \pm 3.7 \%$ for Ti. The multi-element analyses of core 214 were performed at the AWI using an ICP sector field mass spectrometer (ICP-MS, Thermo Finnigan MAT Element 2 with an Apex- $Q$ nebulizer). Rhodium was added to the samples as an internal standard. For all elements, the analytical precision was better than $3 \%$. The error with respect to the certified concentrations of elements in the standard material was less than $5 \%$.

Excess $\mathrm{Ba}\left(\mathrm{Ba}_{\mathrm{xs}}\right)$ was calculated following the approach of Dymond et al. (1992):

$\mathrm{Ba}_{\mathrm{xs}}=\mathrm{Ba}_{\text {total }}-\left(\mathrm{Al} \times \mathrm{Ba} / \mathrm{Al}_{\text {detritus }}\right)$
We used the lowest $\mathrm{Ba} / \mathrm{Al}$ mass ratio determined for the two cores (0.004) as an estimate for the detrital fraction $\left(\mathrm{Ba} / \mathrm{Al}_{\text {detritus }}\right)$. While this ratio is at the lower end of values typical for crustal rocks (Taylor, 1964; Rösler and Lange, 1972 ), it fits well to the global average ratio (0.0037) proposed by Reitz et al. (2004) and the ratio in Danube River sediment (0.005) (Yiğiterhan and Murray, 2008). According to Panin and Jipa (2002), the Danube River is the main source of suspended material discharged into the northwestern Black Sea. Although the calculation of $\mathrm{Ba}_{\mathrm{xs}}$ using a single $\mathrm{Ba} / \mathrm{Al}$ mass ratio bears the risk of neglecting changing detrital $\mathrm{Ba} / \mathrm{Al}$ ratios over time, it is regarded as sufficient within the frame of this study.

\subsubsection{Total organic carbon}

Total organic carbon (TOC) concentrations in samples from both cores were determined with a Leco CS-200 combustion analyzer. Before combustion, the sediment was decalcified with $12.5 \% \mathrm{HCl}$, washed twice, and dried on a heating plate. The TOC contents in core 214 (up to $8 \%$ ) were published by Blumenberg et al. (2009).

\subsubsection{Optical analysis of barite particles}

Heavy mineral grains were examined at selected depths in core 214 (0-2 cmbsf, 64-66 cmbsf, 94-96 cmbsf, 120 $122 \mathrm{cmbsf}$, and $150-152 \mathrm{cmbsf}$ ) at the Laboratoire des Sci- 
ences du Climat et de ÍEnvironnement (LSCE). About $250 \mu \mathrm{g}$ of bulk sediment were dispersed in ethanol using ultrasonification and subsequently filtered onto nuclepore filters $(0.2 \mu \mathrm{m}$ pore size). The filters were fixed onto sample stubs, coated with a thin layer of carbon, and introduced into a scanning electron microscope (SEM) (type JEOL JSM 840) coupled to an energy dispersive spectrometer (EDS) and an automated particle counting and classification system. The first image was processed at $500 \times$ magnification from the backscattered electron beam. After conversion into a binary image, a threshold that allows for the detection of heavy minerals such as barite $\left(\mathrm{BaSO}_{4}\right)$, rutile $\left(\mathrm{TiO}_{2}\right)$, and pyrite $\left(\mathrm{FeS}_{2}\right)$ was adjusted. The mineralogy of each particle was determined with an X-ray spectrum $(15 \mathrm{kV}, 3 \mathrm{~s})$. Using this method, up to 3400 grains per sample were classified automatically. Pictures of selected barites visualized in the secondary electron mode were used to classify the grains according to their shapes. The procedure was described in detail by Robin et al. (2003).

\subsection{Geochemical model}

The SMT migration resulting from the increase in water column sulfate concentrations and variable TOC fluxes during the Holocene Black Sea flooding was simulated using a one-dimensional reaction-transport model (e.g., Boudreau, 1997; Mogollón et al., 2011 (Eqs. (1) and (2)). Initially, a transport model for a conservative tracer $\left(\mathrm{Mg}^{2+}\right)$ was used to discern speed and timing of the change from freshwater to marine conditions. Then, a model comprised two dissolved species (methane, sulfate), one solid species (TOC, chemically represented as carbohydrate, $\mathrm{CH}_{2} \mathrm{O}$ ), and three reactions (organoclastic sulfate reduction $-R_{O S R}$, methanogenesis $-R_{M E T}$, and AOM $-R_{A O M}$ ), in addition to burial and diffusion processes, was used to simulate the shift of the SMT with time (e.g., Mogollón et al., 2011).

Organoclastic sulfate reduction and methanogenesis are related to the degradation of organic matter through the stoichiometry of Eqs. (2) and (3), respectively. Organic matter degradation $\left(R_{\mathrm{CH}_{2} \mathrm{O}}\right)$ is described according to the reactive continuum model using a gamma function distribution for the reactivity of the organic matter pools (Boudreau and Ruddick, 1991), while AOM was depicted as a bimolecular rate constant. The parameters employed in the model and the equations used for the model are depicted in Tables 1 and 2, respectively.

The sites investigated in this study are unaffected by gas seepage and advective fluid flow. Due to the lack of site-specific temperature data, it was assumed to be constant with depth and time at $8.5^{\circ} \mathrm{C}$ (Özsoy and Ünlüata, 1997). As no porosity or biologically induced mixing data were obtained at these sites, an exponentially decreasing porosity profile was assumed (Table 1), while biologically induced mixing was not taken into account, which is a reasonable assumption for anoxic settings. Although such simplifications may ultimately impact the parameters selected for the model, the uncertainties do not significantly alter the main conclusions of the simulations, and are commonly employed in reaction-transport modeling (e.g., Jørgensen et al., 2001, 2004). The barium cycle was excluded from the model due to the independent variations exhibited by $\mathrm{Ba}_{\mathrm{xs}}$ and TOC contents (see below) even within the diagenetically "unaffected" section, which would limit the ability to constrain the barite flux. The consumption/production of sulfate from barite production/dissolution is assumed to be negligible compared to the sulfate flux and methanotrophic sulfate reduction $(\mathrm{AOM})$, respectively.

The upper boundary conditions for the dissolved species were defined by their respective bottom water concentrations. The lower model boundaries for the dissolved species were defined as zero gradient boundaries, and were placed deep enough (50 mbsf) as to minimize their impact on the top 7 meters of the sediment (Table 1). The top boundary condition for organic matter was described as the TOC flux to the sediment, which was varied over different time intervals in order to fit the data (Table 3). Further initial conditions were as follows: $0 \mathrm{mM}$ for sulfate (freshwater conditions), steady state lacustrine conditions for methane and organic carbon, and $0.126 \mathrm{mM}$ for $\mathrm{Mg}^{2+}$ (Falkner et al., 1991).

A $20 \mathrm{~cm}$ thick slump at site 214 during the Unit I/II transition (3.5 kyr BP) was simulated as an instantaneous deposit with a constant pore water chemistry (equal to the bottom water chemistry) and a constant TOC content of $8 \%$, which was assumed to consist of highly refractory material and thus was assumed unreactive for modeling purposes.

\section{RESULTS AND DISCUSSION}

\subsection{Sediment composition and core stratigraphy}

For core 755, a linear extrapolation of pore water sulfate concentrations to the sediment-water interface (SWI) indicates a loss of the top $\sim 35 \mathrm{~cm}$ during core retrieval (Fig. 2d). The sampled interval appears unaffected by turbidites or slumps and contains all three Black Sea lithological units. The Unit III/II boundary ( $\sim 7.5 \mathrm{kyr} \mathrm{BP})$ is marked by the onset of gradually increasing TOC contents at $215 \mathrm{cmbsf}$ (Fig. 2a). The maximum TOC content of $8.6 \mathrm{wt} . \%$ is reached at $192 \mathrm{cmbsf}$. At $202 \mathrm{cmbsf}$, solid phase $\mathrm{Ca}$ and $\mathrm{Sr}$ (Fig. $2 \mathrm{~b}$ and c) show pronounced peaks $\left(140.8 \mathrm{~g} \mathrm{~kg}^{-1}\right.$ and $1.85 \mathrm{~g} \mathrm{~kg}^{-1}$, compared to background values of about $60 \mathrm{~g} \mathrm{~kg}^{-1}$ and $0.2 \mathrm{~g} \mathrm{~kg}^{-1}$, respectively) indicating the characteristic aragonite layer located in the lower Unit II (Ross and Degens, 1974; Jones and Gagnon, 1994; Morse et al., 2007). The sharp increase in Ca contents from $39.3 \mathrm{~g} \mathrm{~kg}^{-1}$ at $100 \mathrm{cmbsf}$ to $87.4 \mathrm{~g} \mathrm{~kg}^{-1}$ at $98 \mathrm{cmbsf}$ marks the Unit II/I boundary.

The stratigraphy for core 214 (Fig. 3a-h) was established by Blumenberg et al. (2009). The Unit III/II boundary is located at $245 \mathrm{cmbsf}$. A slump deposit between 80 and $105 \mathrm{cmbsf}$ prevents a precise identification of the Unit II/I boundary. However, the sediment below the slump deposit is identified as Unit II, whereas the material above it belongs to Unit I. A noticeable turbidite sequence occurs at $133-145.5 \mathrm{cmbsf}$. Further below, several thin turbidites appear as light gray clayey intervals at $161.5-165,187-$ $188.5, \quad 197-199,202-203.5, \quad 214-217$, and 225.5-228.5 cmbsf. Three additional coarse-grained turbidites are 
Table 1

Model parameters, note that some values are time and/or depth dependent (see text and Table 3).

\begin{tabular}{|c|c|c|c|c|}
\hline Name & Symbol & Value & Unit & References \\
\hline Porosity at $\mathrm{SWI}^{\mathrm{a}}$ & $\varphi_{0}$ & 0.85 & & Assumed $^{\mathrm{b}}$ \\
\hline Porosity at depth ${ }^{\mathrm{a}}$ & $\varphi_{\infty}$ & 0.60 & & Assumed $^{\mathrm{b}}$ \\
\hline Porosity attenuation with depth ${ }^{\mathrm{a}}$ & $\gamma$ & 0.007 & $\mathrm{~cm}^{-1}$ & Assumed $^{\mathrm{b}}$ \\
\hline 1 st constant for sulfate diffusion & $m_{0, \mathrm{SO}_{4}^{2-}}$ & $4.88 \mathrm{e}-6$ & $\mathrm{~cm}^{2} \mathrm{~s}^{-1}$ & Boudreau $(1997)^{\mathrm{c}}$ \\
\hline 2nd constant for sulfate diffusion & $m_{1, \mathrm{SO}_{4}^{2-}}$ & $0.232 \mathrm{e}-6$ & $\mathrm{~cm}^{2} \mathrm{~s}^{-1}{ }^{\circ} \mathrm{C}^{-1}$ & Boudreau $(1997)^{\mathrm{c}}$ \\
\hline 1 st constant for sulfate magnesium & $m_{0, \mathrm{Mg}^{2}}=$ & $3.43 \mathrm{e}-6$ & $\mathrm{~cm}^{2} \mathrm{~s}^{-1}$ & Boudreau $(1997)^{\mathrm{c}}$ \\
\hline 2nd constant for sulfate magnesium & $m_{1, \mathrm{Mg}^{2}=}$ & $0.144 \mathrm{e}-6$ & $\mathrm{~cm}^{2} \mathrm{~s}^{-1}{ }^{\circ} \mathrm{C}^{-1}$ & Boudreau $(1997)^{\mathrm{c}}$ \\
\hline Pre-exponential factor methane diffusion & $A^{1, \mathrm{Mg}^{-1}}$ & $3047 e-5$ & $\mathrm{~cm}^{2} \mathrm{~s}^{-1}$ & Boudreau (1997) ${ }^{\mathrm{d}}$ \\
\hline Activation energy for methane diffusion & $E_{a}$ & 18.36 & $\mathrm{~kJ} \mathrm{~mol}^{-1}$ & Boudreau (1997) \\
\hline Bimolecular AOM rate constant & $k_{A O M}$ & 5.0 & $\mathrm{mM}^{-1} \mathrm{yr}^{-1}$ & Mogollón et al., 2011 \\
\hline Sulfate half-saturation concentration & $K_{\mathrm{SO}^{2-}}$ & 0.1 & $\mathrm{mM}$ & Mogollón et al., 2011 \\
\hline Temperature & $T^{\mathrm{SO}_{4}}$ & 8.5 & ${ }^{\circ} \mathrm{C}$ & Ref in text. \\
\hline Burial velocity of solids below compacted layer ${ }^{\mathrm{e}}$ & $w_{\infty}$ & Table 3 & $\mathrm{~cm} \mathrm{kyr}^{-1}$ & This study \\
\hline Average age of fast-decaying TOC pools & $\alpha$ & Footnote $^{\mathrm{f}}$ & $\mathrm{yr}$ & Boudreau and Ruddick (1991) \\
\hline Distribution of most refractive TOC pools & $v$ & Table 3 & & Boudreau and Ruddick (1991) \\
\hline Organic matter flux into the sediment & $\mathrm{F}_{\mathrm{CH}_{2} \mathrm{O}}$ & Table 3 & $\mathrm{~mol} \mathrm{~m}^{2} \mathrm{yr}^{-1}$ & This study \\
\hline Top boundary $(0)$ condition sulfate, magnesium ${ }^{\mathrm{g}}$ & {$[X]_{0}$} & Footnote $^{\text {h }}$ & $\mathrm{mM}$ & This study \\
\hline Top boundary condition methane & {$\left[\mathrm{CH}_{4}\right]_{0}$} & 0.0 & $\mathrm{mM}$ & This study \\
\hline Bottom boundary $(L)$ conditions sulfate, methane, magnesium & $\left.\frac{\partial[X]}{\partial z}\right|_{I}$ & 0.0 & $\mathrm{mM} \mathrm{cm}^{-1}$ & This study \\
\hline Contemporary $\mathrm{Mg}^{2+}$ bottom water concentration & {$\left[M^{1 L}\right]_{0, t=0 k r y B P}$} & 34.0 & $\mathrm{mM}$ & This study \\
\hline Contemporary sulfate bottom water concentration & {$\left[\mathrm{SO}_{4}^{2-}\right]_{0, t=0 \mathrm{krvBP}}$} & 16.0 & $\mathrm{mM}$ & This study \\
\hline
\end{tabular}

${ }^{\mathrm{a}} \varphi=\varphi_{\infty}+\left(\varphi_{0}-\varphi_{0}\right) \exp (-\gamma z)$, where $z$ is the sediment depth.

${ }^{\mathrm{b}}$ No porosity data available for the study sites.

${ }^{\text {c }} D_{X}=\left(m_{0, X}+m_{1, X} T\right) /(1-2 \ln (\varphi))$.

${ }^{\mathrm{d}} D_{C_{H_{4}}}=A \exp \left(-E_{a} /(R T)\right) /(1-2 \ln (\varphi))$, where $R$ is the universal gas constant.

e $w=w_{\infty}\left(1-\varphi_{\infty}\right) /(1-\varphi)$.

f $\alpha=4970 \exp \left(-0.0296 w_{\infty}\right)$.

g $[X]$ is the concentration of species $X$.

h $[X]_{0, t}=\min \left\{[X]_{0, t=0 k y r B P},[X]_{0, t=0 k y r B P}(t-9.3) / 7\right\}$, where $t$ is time in kyr BP.

Table 2

Mathematical description of the reaction rates employed in the reaction-transport model.

\begin{tabular}{lll}
\hline Rate & Symbol & Equation \\
\hline Organic matter degradation & $R_{\mathrm{CH}_{2} \mathrm{O}}$ & $\frac{\underline{v}}{\alpha}\left[\mathrm{CH}_{2} \mathrm{O}\right]^{1+1 / v}$ \\
Organoclastic sulfate reduction & $R_{O S R}$ & $0.5 \varepsilon\left(f_{\mathrm{SO}^{1 / v}}^{2-}\right) R_{\mathrm{CH}_{2} \mathrm{O}}$ \\
Methanogenesis & $R_{M E T}$ & $0.5 \varepsilon\left(1-f_{\mathrm{SO}^{2-}}\right) R_{\mathrm{CH}_{2} O}$ \\
Anaerobic oxidation of methane & $R_{A O M}$ & $k_{A O M}\left[\mathrm{CH}_{4}\right]\left[\mathrm{SO}_{4}^{2-}\right]$ \\
\hline
\end{tabular}

$[X]$ is the concentration of species $X$.

$\varepsilon$ is a conversion factor which accounts for the changes from solid phase units to pore water units.

$f_{\mathrm{SO}_{4}^{2-}}=1$ if $\left[\mathrm{SO}_{4}^{2-}\right]>K_{\mathrm{SO}_{4}^{2-}}$ or $f_{\mathrm{SO}_{4}^{2-}}=\left[\mathrm{SO}_{4}^{2-}\right] / K_{\mathrm{SO}_{4}^{2-}}$ if $\left[\mathrm{SO}_{4}^{2-}\right] \leqslant K_{\mathrm{SO}_{4}^{2-}}$.

Table 3

Time and site-specific parameters.

\begin{tabular}{|c|c|c|c|c|c|c|c|}
\hline \multirow[t]{2}{*}{ Time interval (kyr BP) } & \multirow[t]{2}{*}{ Unit } & \multicolumn{3}{|l|}{ Site 755} & \multicolumn{3}{|l|}{ Site 214} \\
\hline & & $F_{\mathrm{CH}_{2} \mathrm{O}}\left(\mathrm{mol} \mathrm{m}^{-2} \mathrm{yr}^{-1}\right)$ & $w_{\infty}\left(\mathrm{cm} \mathrm{kyr}^{-1}\right)$ & $v$ & $F_{\mathrm{CH}_{2} \mathrm{O}}\left(\mathrm{mol} \mathrm{m}^{-2} \mathrm{yr}^{-1}\right)$ & $w_{\infty}\left(\mathrm{cm} \mathrm{kyr}^{-1}\right)$ & v \\
\hline $9.3-7.5$ & III & 0.27 & 11.0 & 0.65 & 0.1 & 4.0 & 0.65 \\
\hline $7.5-6.2$ & II & 1.8 & 22.0 & 0.125 & 2.7 & 28.6 & 0.2 \\
\hline $6.2-4.5$ & II & 0.58 & 22.0 & 0.125 & 1.1 & 28.6 & 0.2 \\
\hline $4.5-3.5$ & II & 0.58 & 22.0 & 0.125 & 0.6 & 28.6 & 0.2 \\
\hline $3.5-0.0$ & I & 0.34 & 15.3 & 0.125 & 0.35 & 14.8 & 0.2 \\
\hline
\end{tabular}

identified at 268-276, 337-339, and 387-390 cmbsf. Most turbidites have higher $\mathrm{Ba} / \mathrm{Al}$ ratios than the rest of the core $(>0.009$ compared to $\sim 0.005$; Fig. $3 \mathrm{~g}$ ), but fairly low $\mathrm{Ca}$ and TOC contents. This probably reflects an increased dilution of the latter two components by higher detrital Si contents in the turbiditic deposits. 


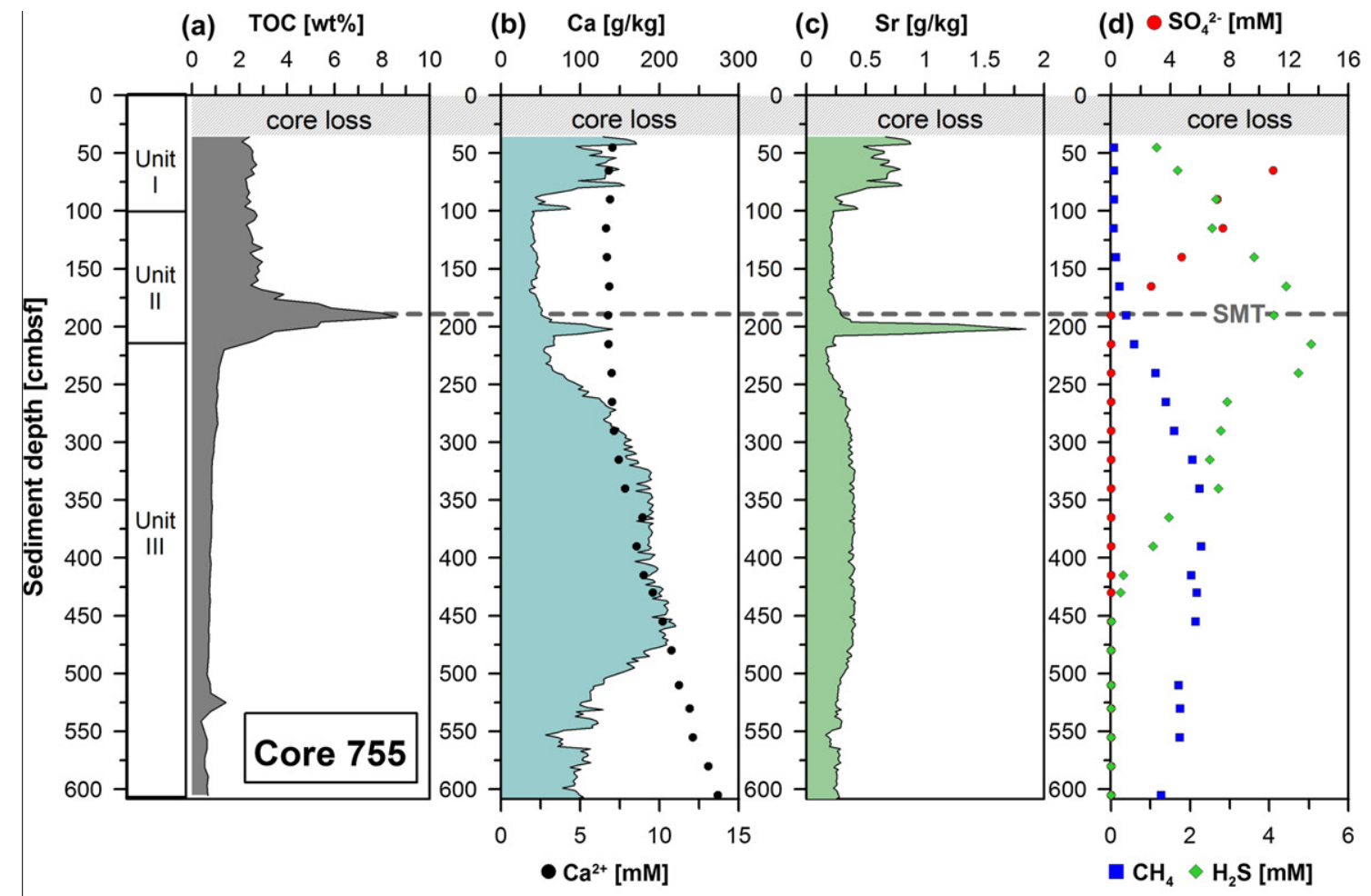

$\begin{array}{ll}\text { (b) } & \mathbf{C a}[\mathbf{g} / \mathbf{k g}] \\ 0 & 100 \quad 200\end{array}$

(c) $\mathrm{Sr}[\mathrm{g} / \mathrm{kg}]$

(d) $\bullet \mathrm{SO}_{4}{ }^{2-}[\mathrm{mM}]$

(e) Alkalinity [mmol(eq)/l]

(f) $\quad B a[g / k g]$

(g) Ba/Al

(h) $\mathrm{Ba}_{\mathrm{xs}}[\mathrm{mg} / \mathrm{kg}]$

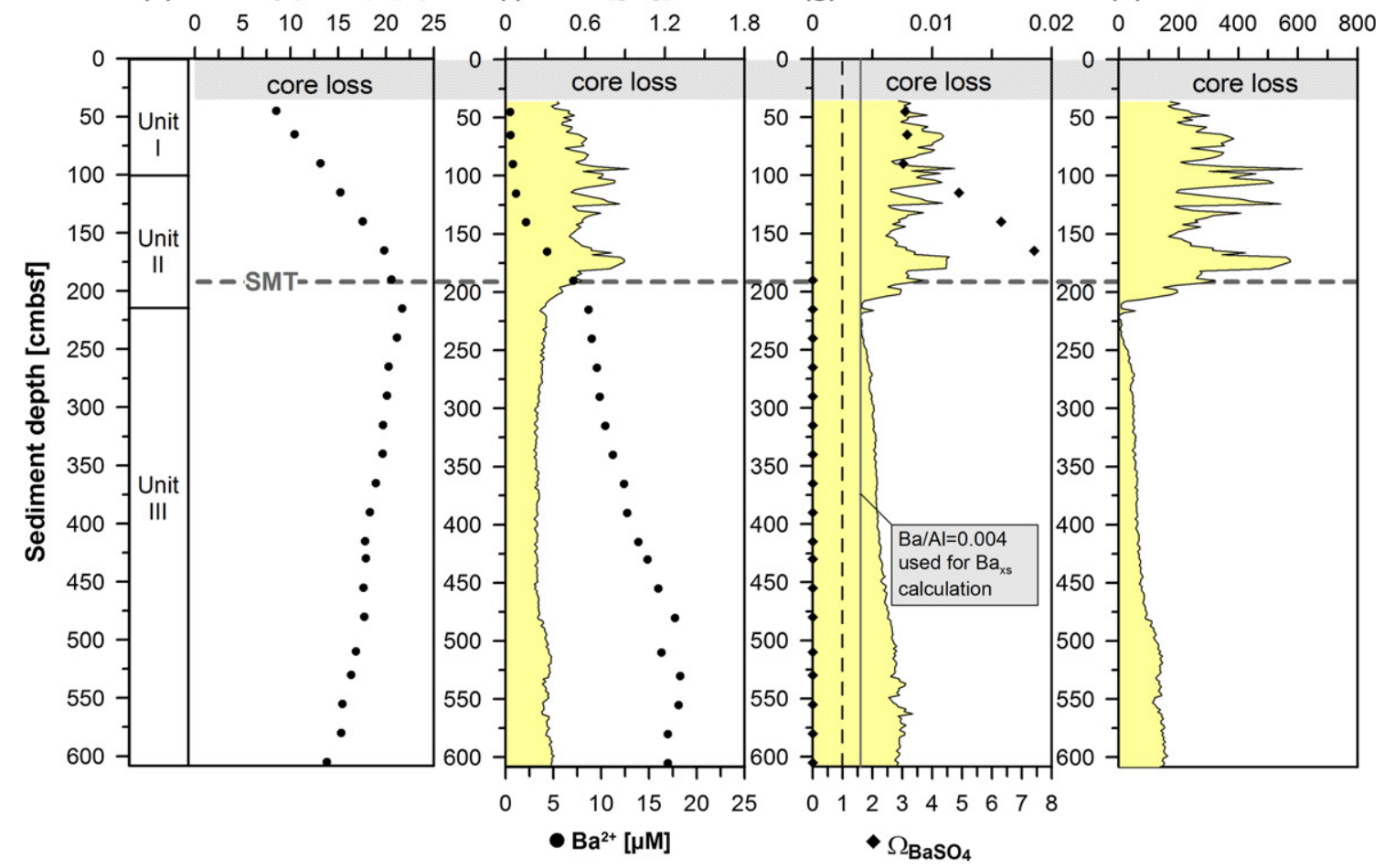

Fig. 2. Geochemical pore water and solid phase data of gravity core $755(\mathrm{a}-\mathrm{h})$. The horizontal dashed line indicates the position of the SMT. The uppermost $\sim 35 \mathrm{~cm}$ of core 755 were lost during core retrieval (see text). The vertical dashed line at $\Omega_{\mathrm{BaSO} 4}=1$ in $\mathrm{g}$ ) indicates saturation with respect to $\mathrm{BaSO}_{4}$. Note that the methane data at depth is probably not trustworthy (see text).

\subsection{Sedimentation rates}

The sedimentation rates were calculated based on observable geochemical transitions between the different lithological units, and thus reflect time-averaged values for the different units. These calculations ignore possible effects of erosion and/or intervals of fast deposition (with the exception of the $20 \mathrm{~cm}$ thick slump at site 214 at the Unit II 


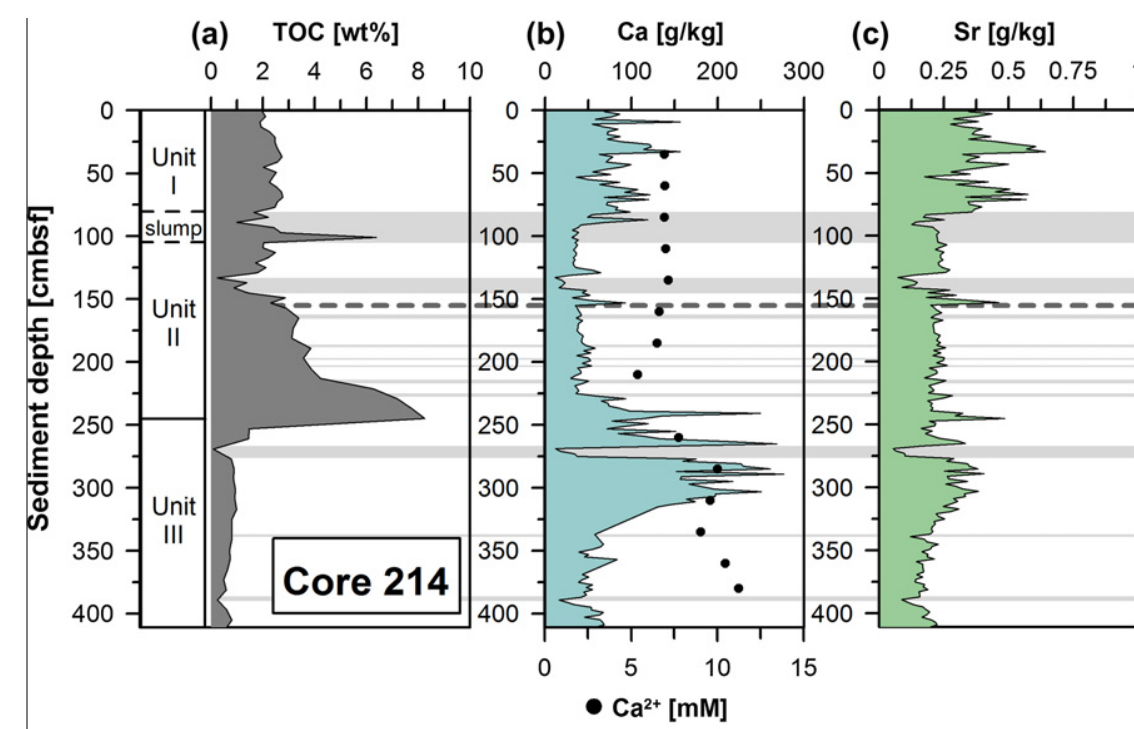

(d) $\bullet \mathrm{SO}_{4}{ }^{2-}[\mathrm{mM}]$

(e) Alkalinity [mmol(eq)/l]

(f) $\mathrm{Ba}[\mathrm{g} / \mathrm{kg}]$

(g)
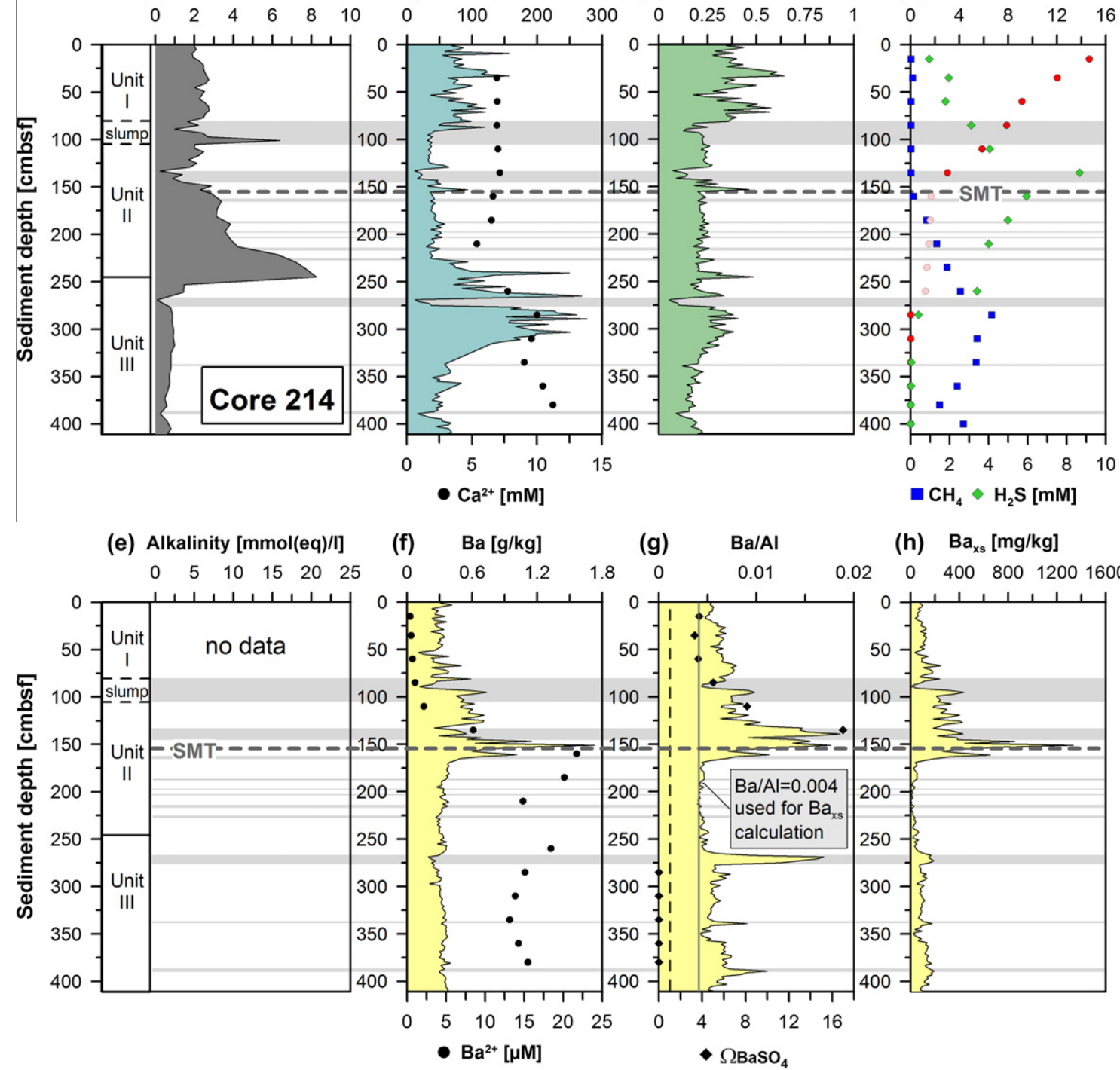

Fig. 3. Geochemical pore water and solid phase data of gravity core $214(\mathrm{a}-\mathrm{h})$. The light grey shaded horizontal bars indicate disturbed sediment layers (slumps, turbidites). The horizontal dashed line marks the position of the SMT. The light red dots in (d) indicate values potentially affected by sulfide oxidation during sample storage. The saturation state with respect to barite in (g) is not shown for this core interval (150-175 cm) because of the questionable sulfate values. The vertical dashed line in $\mathrm{g}$ ) at $\Omega_{\mathrm{BaSO} 4}=1$ indicates saturation with respect to $\mathrm{BaSO}_{4}$. Note that the methane data at depth is probably not trustworthy (see text).

- Unit I boundary that was explicitly taken into account in the simulations). The assumed sediment compaction (Table 1) was considered when calculating the sedimentation rates.

The burial velocity of solids at the SWI ( $w_{0}$, Table 1$)$ for site 755 is $41 \mathrm{~cm} \mathrm{kyr}^{-1}$ for Unit I and $59 \mathrm{~cm} \mathrm{kyr}^{-1}$ for Unit II. The respective values for core 214 are $39 \mathrm{~cm} \mathrm{kyr}^{-1}$ (Uni$\mathrm{t}$ I) and $76 \mathrm{~cm} \mathrm{kyr}^{-1}$ (Unit II). The $w_{0}$ values for Unit III were calculated only for the sections reflecting the limnicmarine transition according to Major et al. (2002). It was shown by Bahr et al. (2005) that this transition interval is characterized by fairly low $\mathrm{Ca}$ contents and high sedimentary $\mathrm{Ti} / \mathrm{Ca}$ ratios, indicating a dominance of detrital components over biogenic carbonate. In our cores (Ti/Ca not shown), the intervals 215-255 cmbsf (core 755) and 245$260 \mathrm{cmbsf}$ (core 214) represent this change from limnic to brackish/marine conditions. In core 214 , determining the limnic-marine transition was complicated by several turbidites within the respective section. The approximated average $w_{0}$ values for the transition interval are $29 \mathrm{~cm} \mathrm{kyr}^{-1}$ for core 755 and $11 \mathrm{~cm} \mathrm{kyr}^{-1}$ for core 214 . These results agree with Bahr et al. (2005), who observed similar thicknesses for Units I and II in five cores (western Black Sea) over a transect from $465 \mathrm{~m}$ to almost $2000 \mathrm{~m}$ water depth, but large variations in the thickness of Unit III.

\subsection{Depth of the sulfate-methane transition}

The pore water profiles of $\mathrm{SO}_{4}^{2-}, \mathrm{CH}_{4}, \mathrm{H}_{2} \mathrm{~S}$, alkalinity, and $\mathrm{Ca}^{2+}$ of cores 755 and 214 are illustrated in Figs. 2 and 3. For both sites, the depth profiles indicate a current SMT within Unit II at about $190 \mathrm{cmbsf}$ for core 755 (501 mbsl), and 150-155 cmbsf for core 214 (1686 mbsl). 


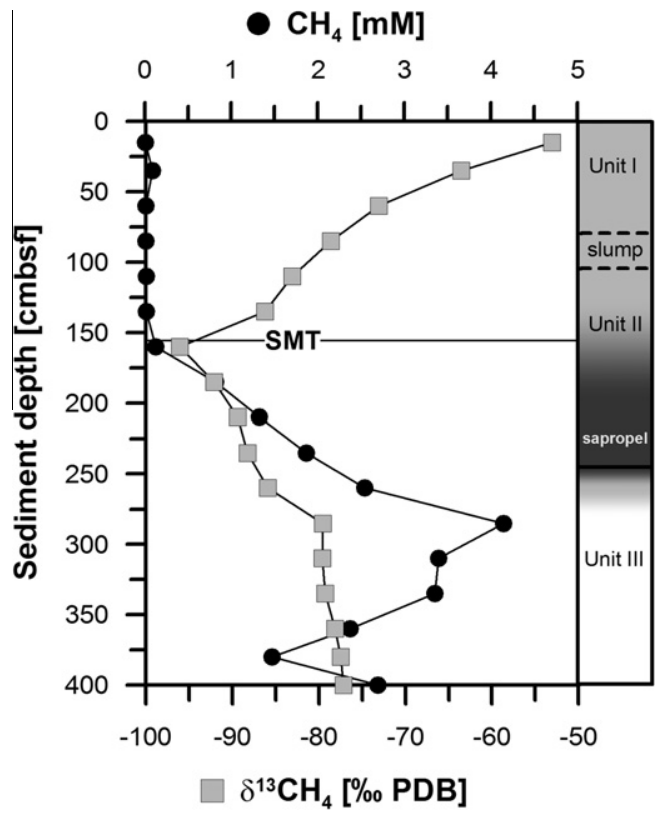

Fig. 4. Concentrations and $\delta^{13} \mathrm{C}_{\mathrm{CH} 4}$-values of methane of core 214. Strong ${ }^{13} \mathrm{C}_{\mathrm{CH} 4}$-depletion within the lower Unit II suggests microbial formation of methane.

Core 755 shows an expanded zone ( $\sim 140-180 \mathrm{cmbsf})$ of methane and sulfate co-existence. A similar tailing of the methane profile was observed in other Black Sea sediments (Reeburgh et al., 1991; Jørgensen et al., 2001; Knab et al., 2009). These studies attributed methane tailing in the sulfate zone to incomplete AOM, which could, in turn, be attributed to the dynamics of reactive intermediates involved in AOM (Dale et al., 2006, 2008; Holmkvist et al., 2011).

At site 214, there is evidence for a microbial origin of the upward diffusing methane. The Unit II sapropel is completely located below the current SMT (Figs. 3 and 4), favoring in situ methanogenesis as the ultimate step in the microbial degradation of sapropel TOC (e.g., Martens and Klump, 1984) as indicated by a strong ${ }^{13} \mathrm{C}_{\mathrm{CH} 4}$-depletion (about $-78 \%$ ). The shift to even more negative values at the transition into Unit II suggests a methane source within the sapropel (Fig. 4). The most negative $\delta^{13} \mathrm{C}_{\mathrm{CH} 4}$ value $(-95 \%)$ was found directly at the SMT. Strongly negative values possibly result from successive carbon cycling in this biogeochemical reaction zone. Microbial methane production was shown to occur in shallow Black Sea sediments (Krüger et al., 2005; Knab et al., 2009; Pape et al., 2010). Borowski et al. (1997) proposed that the repeated redox reaction from $\mathrm{CH}_{4}$ to $\mathrm{CO}_{2}$ (by $\mathrm{AOM}$ ) and back to $\mathrm{CH}_{4}$ $\left(\mathrm{CO}_{2}\right.$ reduction) could lead to a progressive ${ }^{13} \mathrm{C}_{\mathrm{CH} 4}$ depletion and extremely negative $\delta^{13} \mathrm{C}_{\mathrm{CH} 4}$ values at the top of the methanogenic zone. The remaining methane diffusing upward from the SMT, however, becomes relatively ${ }^{13} \mathrm{C}$-enriched due to the preferential ${ }^{12} \mathrm{CH}_{4}$ consumption during AOM (Fig. 4, e.g., Whiticar, 1999; Pohlman et al., 2009).

The sulfide profiles at both locations (Figs. 2d and 3d) are consistent with the inferred SMT depths. During
$\mathrm{AOM}, \mathrm{HS}^{-}$as well as $\mathrm{HCO}_{3}^{-}$are liberated into the interstitial water (see Eq. (4)) and increase the alkalinity (Fig. 2e). The sulfide profiles at both sites indicate an upward diffusive flux towards and across the SWI, and a downward flux into the limnic deposits of Unit III. Sulfide concentrations were below detection limit at $480 \mathrm{cmbsf}$ (core 755) and at $360 \mathrm{cmbsf}$ (core 214). According to Jørgensen et al. (2004), Neretin et al. (2004), and Knab et al. (2009), the depletion of $\mathrm{H}_{2} \mathrm{~S}$ within Unit III is attributed to the formation of iron sulfides upon reaction with upward-diffusing $\mathrm{Fe}^{2+}$ that is released from the limnic deposits.

\subsection{Diagenetic barium redistribution}

The EDS spectra of the Ba-containing particles in the five selected samples reveal that $\mathrm{BaSO}_{4}$ is the dominant Ba-containing heavy mineral above the SMT (Table 4). The only other $\mathrm{Ba}-$ mineral detected was gorceixite $\left(\mathrm{BaAl}_{3}(-\right.$ $\left.\left.\mathrm{PO}_{4}\right)\left(\mathrm{PO}_{3} \mathrm{OH}\right)(\mathrm{OH})_{6}\right)$. Nevertheless, these heavy minerals do not account for the bulk sedimentary Ba contents. Additional Ba might be incorporated in silicates and carbonates, but these minerals were not specifically studied by SEM/ EDS. Excess barium was calculated to correct for Ba associated with detrital or carbonate minerals.

At both sites, the sedimentary Ba redistribution strongly depends on the extent of seawater penetration into the limnic sediments, and on the location of the SMT. The dissolved $\mathrm{Ba}^{2+}$ profile at site 755 is characterized by minimum concentrations $(0.5 \mu \mathrm{M})$ near the SWI, and a gradual increase with depth until below the SMT (Fig. 2f). The pore water profile suggests two $\mathrm{Ba}^{2+}$ sources: one situated directly below the SMT at $\sim 200 \mathrm{cmbsf}$ ( $\sim$ Unit II/III boundary), and the other located within the limnic sediments (Unit III) around $500 \mathrm{cmbsf}$ where $\mathrm{Ba}^{2+}$ concentrations reach their maximum $(18.0 \mu \mathrm{M})$. Similarly, at site 214, $\mathrm{Ba}^{2+}$ concentrations increase with depth from $0.4 \mu \mathrm{M}$ near the SWI until a maximum of $22 \mu \mathrm{M}$ is reached directly below the SMT. Further below, however, the $\mathrm{Ba}^{2+}$ concentrations follow a sinusoidal pattern, with relative lows at 210 and $335 \mathrm{cmbsf}$, and relative highs at 260 and $380 \mathrm{cmbsf}$.

The option that deep $\mathrm{Ba}^{2+}$ originates from relict $\mathrm{BaSO}_{4}$ enrichments in Unit III can be discarded due to (1) the limnic nature of this Unit (see below; Smith et al., 2004), and (2) the lack of $\mathrm{Ba}_{\mathrm{xs}}$ peaks that can be correlated with the observed $\mathrm{Ba}^{2+}$ sources (Figs. 2f and $3 \mathrm{f}$ ). Instead, we postulate that $\mathrm{Ba}^{2+}$ desorption from the mineral matrix occurs within Unit III as seawater diffuses into the limnic deposits, similar to $\mathrm{Ba}^{2+}$ desorption from suspended riverine clay minerals across the estuarine mixing zone (Hanor and Chan, 1977; Coffey et al., 1997). Furthermore, in the Baltic Sea, authigenic barite micronodule formation is associated with the liberation of adsorbed $\mathrm{Ba}^{2+}$ from underlying freshwater sediments due to contact with saline water (Suess, 1982; Böttcher and Lepland, 2000). The downward increase in $\mathrm{Ca}^{2+}$ concentrations (Figs. $2 \mathrm{~b}$ and $3 \mathrm{~b}$ ) is also attributed to salinity changes rather than to carbonate dissolution. The deep $\mathrm{Ca}^{2+}$ originates from cation exchange from limnic Ca-rich clay minerals, whereas marine clays are dominated by $\mathrm{Na}, \mathrm{Mg}$, and $\mathrm{K}$ (De Lange, 1983). In contrast, although 
Table 4

Average equivalent diameters for all Ba-containing heavy minerals identified by SEM/EDS. Ba-containing grains larger than $6 \mu \mathrm{m}$ were not detected in any of the samples.

\begin{tabular}{|c|c|c|c|c|c|c|c|c|c|c|}
\hline \multirow{2}{*}{$\begin{array}{l}\text { Depth } \\
\text { [cmbsf] }\end{array}$} & \multirow{2}{*}{$\begin{array}{l}\text { Grains } \\
\text { analysed }\end{array}$} & \multirow{2}{*}{$\begin{array}{l}\text { Heavy } \\
\text { Ba-minerals }\end{array}$} & \multicolumn{7}{|c|}{ Average Equivalent Diameter (AED) } & \multirow{2}{*}{$\begin{array}{l}\text { Sum of heavy } \\
\text { Ba-mineral } \\
\text { grains }\end{array}$} \\
\hline & & & $0.2-0.5 \mu \mathrm{m}$ & $0.5-1 \mu \mathrm{m}$ & $1-2 \mu \mathrm{m}$ & $2-3 \mu \mathrm{m}$ & $3-4 \mu \mathrm{m}$ & $4-5 \mu \mathrm{m}$ & $5-6 \mu \mathrm{m}$ & \\
\hline \multirow[t]{2}{*}{$0-2$} & \multirow[t]{2}{*}{3400} & $\mathrm{BaSO}_{4}$ & 0 & 55 & 51 & 7 & 3 & 2 & 0 & 118 \\
\hline & & Other Ba-containing & 0 & 0 & 2 & 0 & 0 & 0 & 0 & 2 \\
\hline \multirow[t]{2}{*}{$64-66$} & \multirow[t]{2}{*}{2119} & $\mathrm{BaSO}_{4}$ & 0 & 55 & 57 & 5 & 1 & 1 & 0 & 119 \\
\hline & & Other Ba-containing & 0 & 1 & 0 & 0 & 0 & 0 & 0 & 1 \\
\hline \multirow[t]{2}{*}{$94-96$} & \multirow[t]{2}{*}{1459} & $\mathrm{BaSO}_{4}$ & 0 & 86 & 79 & 6 & 3 & 1 & 0 & 175 \\
\hline & & Other Ba-containing & 0 & 1 & 1 & 0 & 1 & 0 & 0 & 3 \\
\hline \multirow[t]{2}{*}{$120-122$} & \multirow[t]{2}{*}{1256} & $\mathrm{BaSO}_{4}$ & 0 & 26 & 30 & 9 & 2 & 0 & 1 & 68 \\
\hline & & Other Ba-containing & 0 & 0 & 1 & 0 & 1 & 0 & 0 & 2 \\
\hline \multirow[t]{2}{*}{$150-152$} & \multirow[t]{2}{*}{957} & $\mathrm{BaSO}_{4}$ & 0 & 35 & 49 & 3 & 1 & 0 & 0 & 88 \\
\hline & & Other Ba-containing & 0 & 0 & 0 & 0 & 0 & 0 & 0 & 0 \\
\hline
\end{tabular}
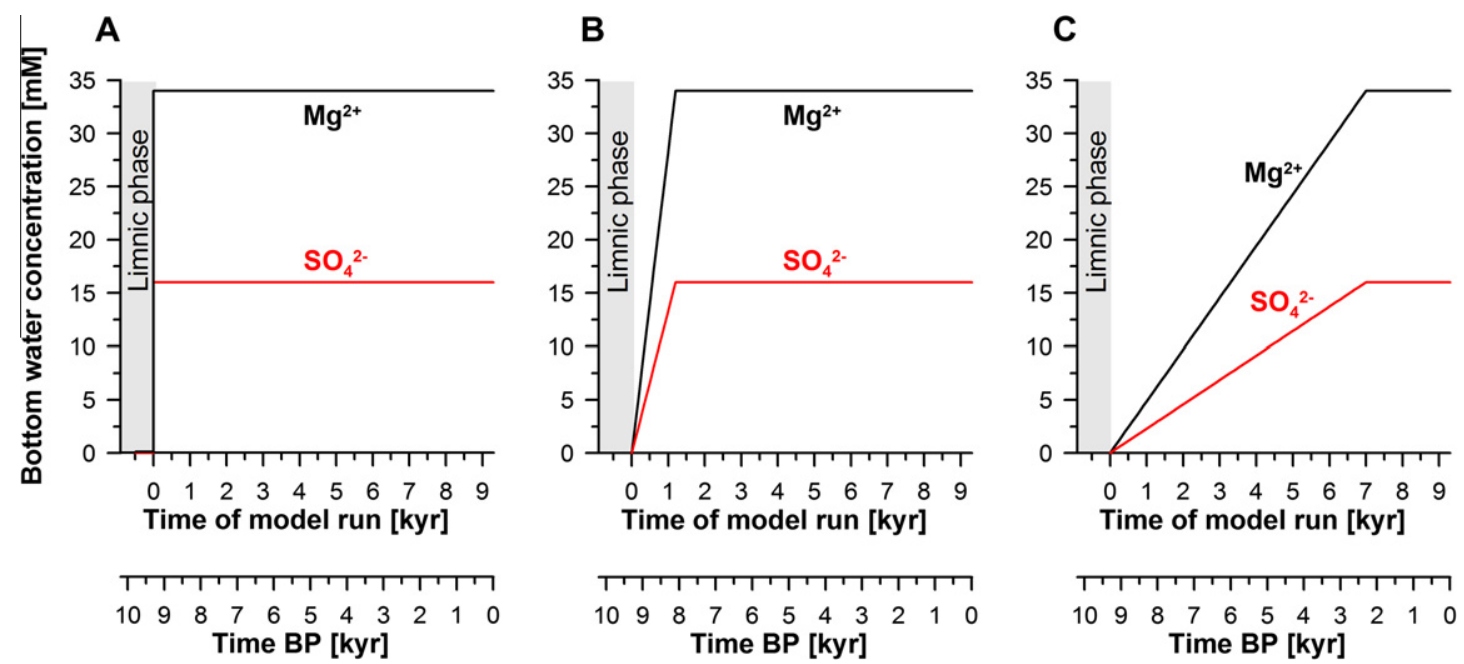

Fig. 5. Scenarios A, B, and C used for the geochemical simulations. (A) Abrupt increase of $\mathrm{SO}_{4}^{2-}$ and $\mathrm{Mg}^{2+}$ in the bottom water immediately after the first seawater intrusion. (B) Gradual increase of $\mathrm{SO}_{4}^{2-}$ and $\mathrm{Mg}^{2+}$ in the bottom water until 1.2 kyrs after the first seawater intrusion. (C) Slow increase of bottom water concentrations until 7 kyrs after first seawater intrusion.
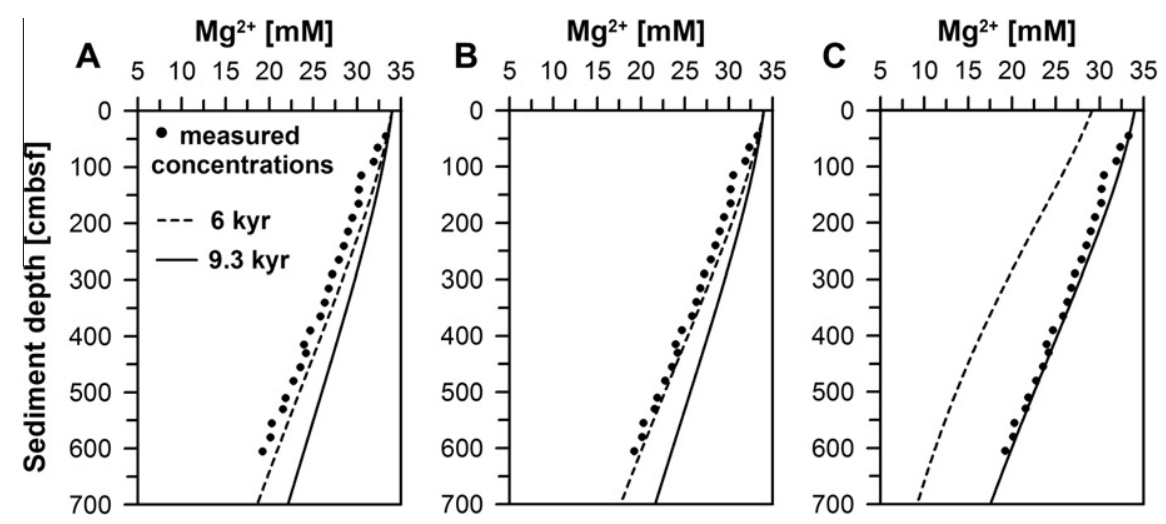

Fig. 6. Modeled pore water profile of the conservative element $\mathrm{Mg}^{2+}$ in comparison to measured concentrations at site 755 (scenarios (A), (B), and $(\mathrm{C})$ according to Fig. 5). The modern upper boundary for $\mathrm{Mg}^{2+}(34 \mathrm{mM})$ was inferred from the extended trendline of the gravity core data. The model simulation showed that the observed data values fit best to scenario (C) (first seawater intrusion at 9.3 kyrs BP followed by a slow increase of $\mathrm{Mg}^{2+}$ in the bottom water until $\sim 2 \mathrm{kyrs} \mathrm{BP}$ ). 

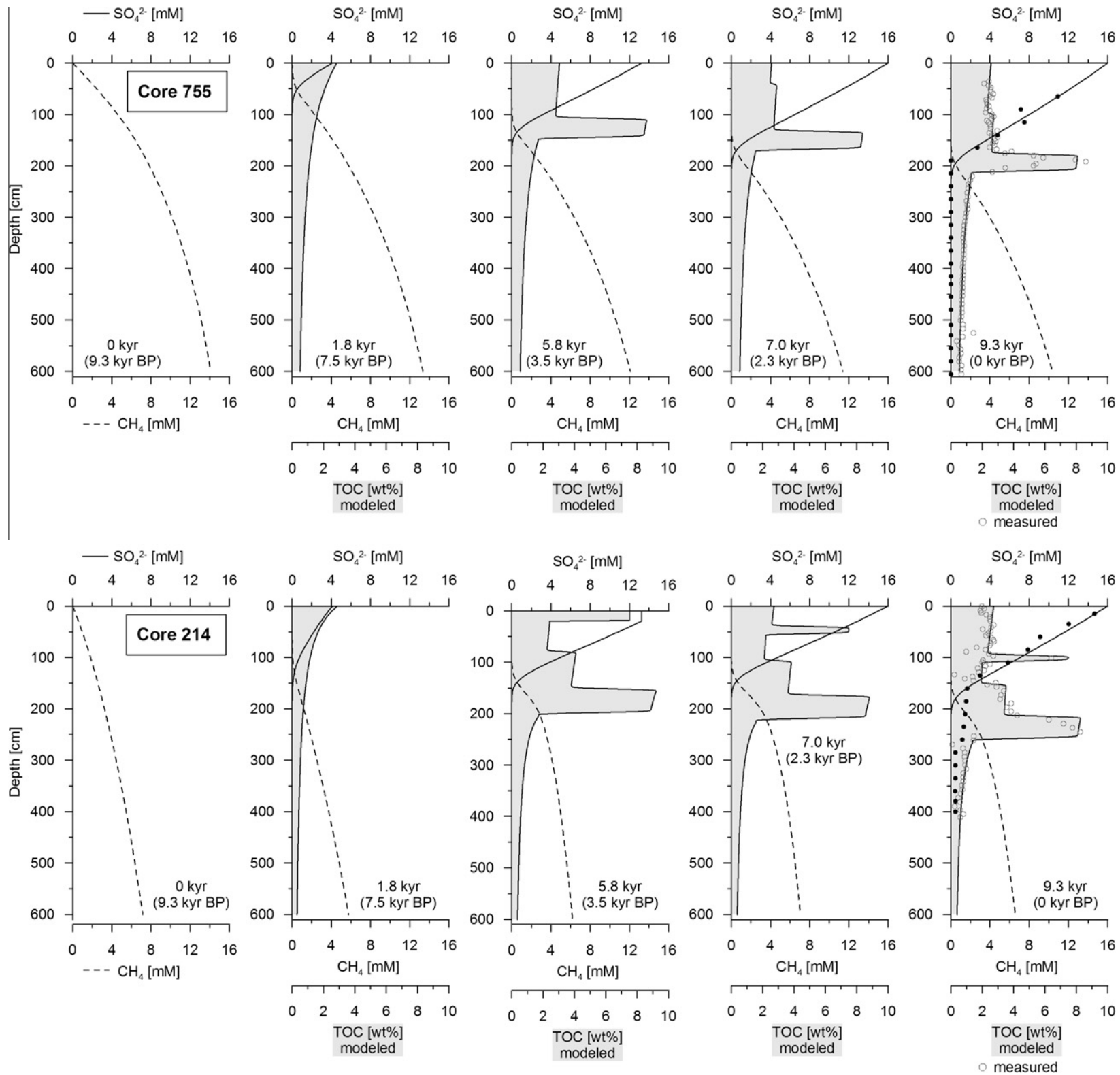

Fig. 7. Results of the reaction-transport simulation concerning the relocation of the SMT at sites 755 (a) and 214 (b) since the Holocene intrusion of Mediterranean seawater. Note that the displayed depth $(6 \mathrm{~m})$ does not represent the complete model length.

Ba can also be bound to carbonates (Dymond et al., 1992; Eagle Gonneea and Paytan, 2006), the contribution of carbonate dissolution to an increase in $\mathrm{Ba}^{2+}$ is considered to be minor.

At site 755 , a broad $\mathrm{Ba}_{\mathrm{xs}}$ peak of $600 \mathrm{mg} \mathrm{kg}^{-1}$ between 150 and $210 \mathrm{cmbsf}$ (Fig. $2 \mathrm{~h}$ ) represents the actively forming diagenetic barite front. Super-saturation $(\Omega>1)$ in the sulfate zone drives authigenic barite precipitation, producing the $\mathrm{Ba}^{2+}$ tailing that extends from 190 to $100 \mathrm{cmbsf}$. Once barite is buried below the SMT (and into the undersaturated zone, $\Omega<1$ ), it dissolves and releases $\mathrm{Ba}^{2+}$, which maintains a steep $\mathrm{Ba}^{2+}$ gradient near the SMT (Fig. 3f). Likewise, at site $214, \mathrm{Ba}^{2+}$ diffuses upwards into the sulfate zone $(\Omega>1)$. Nevertheless, the $\mathrm{Ba}^{2+}$ tailing, extending from 130 to $75 \mathrm{cmbsf}$, indicates a slightly more condensed zone of barite precipitation compared to site 755 , which is most likely due to the higher super-saturation levels at site 214 $\left(\Omega_{\max } \sim 17\right.$ vs. $\left.\Omega_{\max } \sim 8\right)$. The imprint on the pore water profile resulting from $\mathrm{Ba}^{2+}$ release directly below the SMT is also more pronounced at this site (upward $\mathrm{Ba}^{2+}$ flux from the SMT is $0.0246 \mu \mathrm{mol} \mathrm{cm} \mathrm{cm}^{-2} \mathrm{yr}^{-1}$ as opposed to $0.0096 \mu \mathrm{mol} \mathrm{cm}^{-2} \mathrm{yr}^{-1}$ at site 755$)$. This may suggest that the barite front at site 214 , which is currently buried into the zone of under-saturation, is subject to faster dissolution.

At site 214 , two $\mathrm{Ba}_{\mathrm{xs}}$ peaks are found just above and below the SMT. The shallower peak $\left(>1300 \mathrm{mg} \mathrm{kg}^{-1}\right.$ at $151 \mathrm{cmbsf}$ ) represents the current authigenic $\mathrm{BaSO}_{4}$ front. The deeper peak (>700 $\mathrm{mg} \mathrm{kg}^{-1}$ at $161 \mathrm{cmbsf}$ ) partly coincides with a turbidite deposit located at 161-165 cmbsf. Nevertheless, this peak is likely the product of a previous 

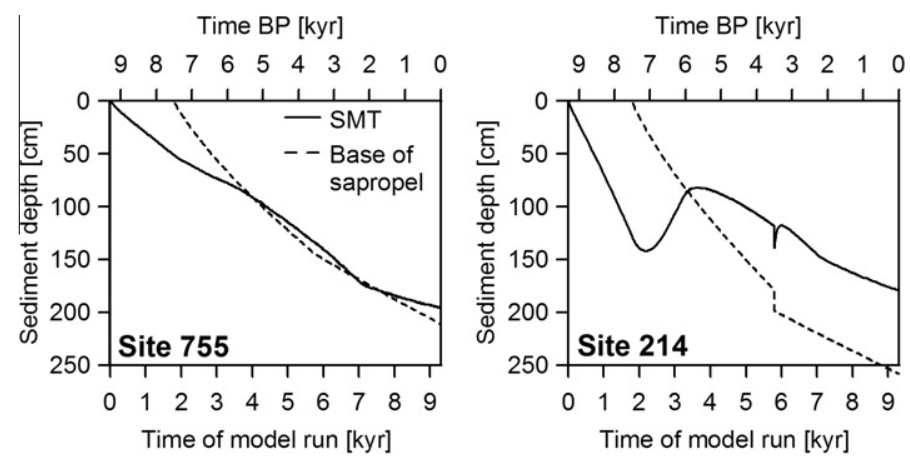

Fig. 8. Simulated depth of the SMT and depth of the base of the Unit II sapropel with time at site 755 and 214.
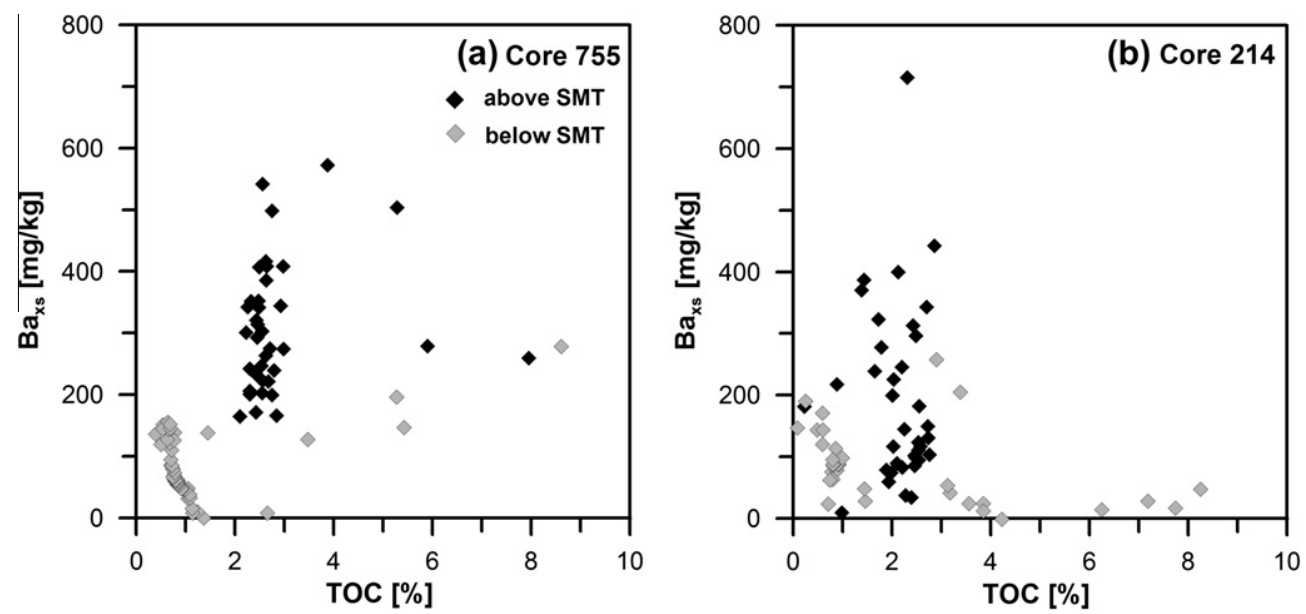

Fig. 9. TOC vs. $\mathrm{Ba}_{\mathrm{xs}}$ in the gravity cores (a) 755 and (b) 214. A correlation between these parameters is neither discernable above nor below the SMT.

authigenic $\mathrm{BaSO}_{4}$ front, similar to the situation in sediments off Namibia (Riedinger et al., 2006), since it occurs mainly in the sediment deposited above the turbidite. As stated above, the deeper peak is associated with a peak in $\mathrm{Ba}^{2+}$ concentrations, indicating that it is currently undergoing dissolution and serves as the main $\mathrm{Ba}^{2+}$ source at site 214 (compare to the study of Riedinger et al., 2006 and sediments at Blake Ridge in Snyder et al., 2007).

In summary, we propose two $\mathrm{Ba}^{2+}$ sources in these Black Sea deposits: Near the SMT, it originates from the dissolution of barite once an older authigenic barite front is buried into the zone of under-saturation with respect to barite. Within Unit III, it originates from desorption processes evoked by the contact of limnic sediment with seawater.

\subsection{Numerical modeling of the SMT migration}

Three scenarios were tested for the timing and speed of the limnic-marine transition in the Black Sea (Fig. 5, Table 1): (A) catastrophic flooding leading to present-day bottom water conditions directly after the connection to the Mediterranean Sea was established (based on assumptions of Ryan et al., 1997), (B) progressive flooding leading to a relatively fast $(1.2 \mathrm{kyr})$ transition towards contemporary conditions, and C) a sluggish seawater intrusion and a slow adjustment to present-day conditions over a 7-kyr span (based on results of Soulet et al., 2010).

In order to assess which marine intrusion scenario (A-C) best reproduces the data set, we simulated the development of the $\mathrm{Mg}^{2+}$ profile at site 755. Dissolved magnesium is considered a conservative element in seawater according to De Lange (1983). Dolomite $\left(\mathrm{CaMg}\left(\mathrm{CO}_{3}\right)_{2}\right)$ precipitation in the studied deposits can be excluded due to opposing trends of pore water $\mathrm{Ca}^{2+}$ and $\mathrm{Mg}^{2+}$ (Figs. $3 \mathrm{~b}$ and 6). An initial $\mathrm{Mg}^{2+}$ concentration of $126 \mu \mathrm{M}$, determined from a freshwater environment (Falkner et al., 1991), was used for the Black Sea deep water prior to the marine intrusion. Given that the flooding started at $\sim 9.3 \mathrm{kyr}$ BP (Bahr et al., 2008), the measured $\mathrm{Mg}^{2+}$ concentrations in the pore water of core 755 fit best to the simulated profile of scenario $\mathrm{C}$ (Fig. 6). Scenarios A and B would result in excessive present-day $\mathrm{Mg}^{2+}$ concentrations in the interstitial water. It should be noted that porosity variations only have a minor effect on the diffusion/advection of $\mathrm{Mg}^{2+}$ into the limnic sediments.

Based on the $\mathrm{Mg}^{2+}$ simulation results, scenario $\mathrm{C}$ was further used to simulate the SMT shift following the marine intrusion into the Black Sea at both sites 755 and 214. For the former, the simulation reveals a gradual deepening of 


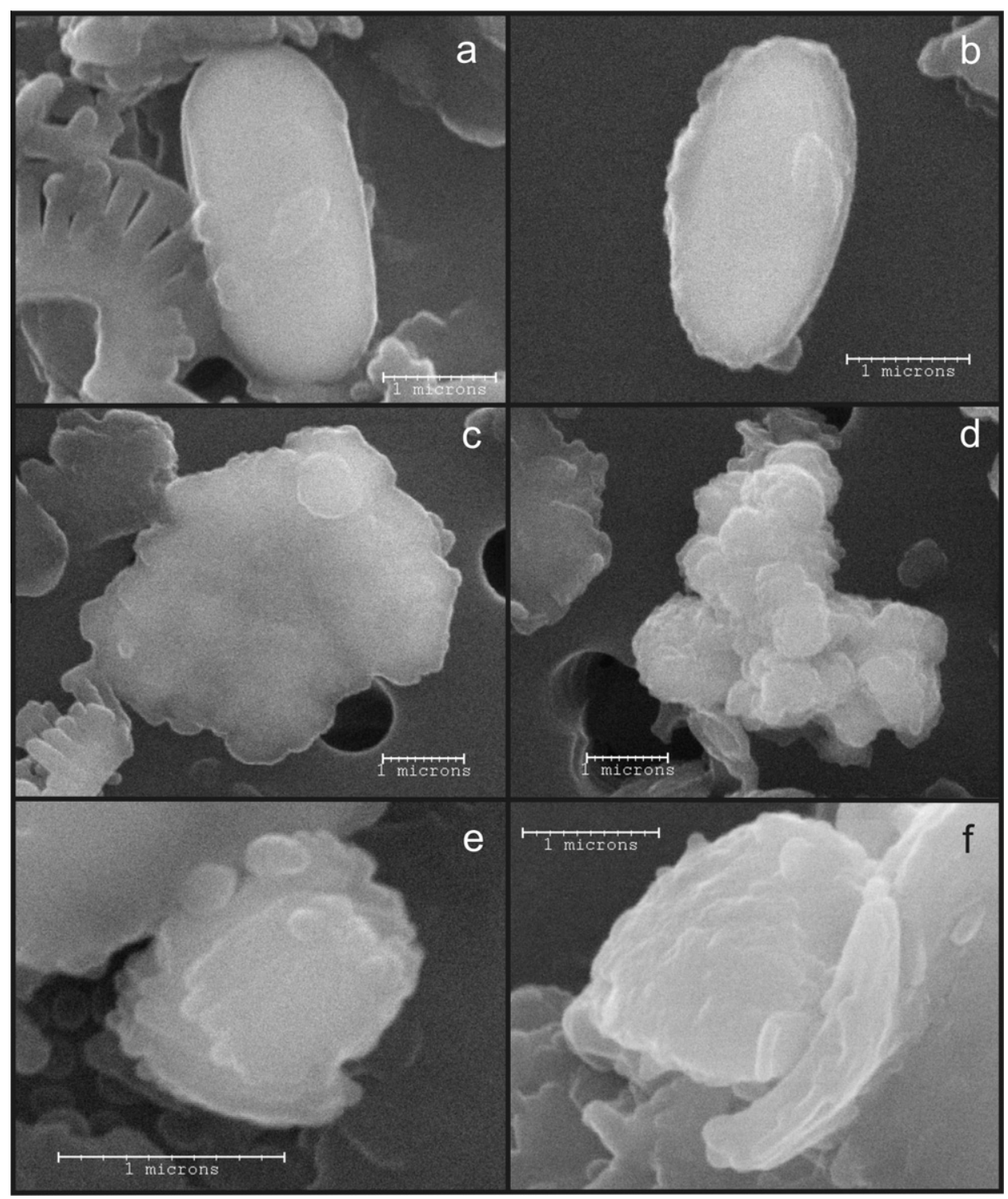

Fig. 10. Barite crystal shapes observed at site 214: Ellipsoidal grains at 0-2 cmbsf (a) and 120-122 cmbsf (b); irregular grains at 0-2 cmbsf (c), $120-122 \mathrm{cmbsf}(\mathrm{d})$, and $150-152 \mathrm{cmbsf}(\mathrm{e})$ and (f).

the SMT as a direct response to the increasing bottom water sulfate concentrations (Figs. 7 and 8), as the methane production in Unit III is insufficient to compensate for the progressive increase of the downward sulfate fluxes. Although the deposition of the Unit II sapropel limits the rate of SMT migration through increased organoclastic sulfate reduction, this process is insufficient to reverse the SMT deepening trend. At site 214, Unit III methanogenesis is also insufficient to compensate for the downward sulfate flux (Figs. 7 and 8). However, the almost 5-fold faster sediment accumulation for Unit II is able to somewhat abate and reverse the downward SMT migration. Through the decrease in the TOC flux during the later stage of Unit II, both organoclastic sulfate reduction and deeper methanogenesis decrease, which allows the SMT to further migrate deeper into the sediment. This deepening trend continues (with a small kink due to the slump deposit) until the bottom water sulfate concentration stabilizes and, similar to site 755 , the downward migration rate of the SMT considerably decreases.

\subsection{Uncoupling of $\mathrm{Ba}$ and TOC deposition with implications for the use of $\mathrm{Ba}$ in anoxic ocean basins}

In the studied cores, TOC and $\mathrm{Ba}_{\mathrm{xs}}$ are, as expected, completely uncoupled below the sulfate-bearing zone. At site 214, such a correlation is also absent within the sulfate-bearing zone (Fig. 9b), whereas at site 755, there is some overlap of the $\mathrm{Ba}_{\mathrm{xs}}$ maximum (160-180 cmbsf) with the TOC peak (175-210 cmbsf). Correlations between TOC and $\mathrm{Ba}_{\mathrm{xs}}$ are common in sediment traps and in sediments largely unaffected by post-depositional organic matter oxidation or diagenetic $\mathrm{BaSO}_{4}$ redistribution (e.g., Dymond et al., 1992; François et al., 1995; Dymond and Collier, 1996; Martínez-Ruiz et al., 2000). The (de)coupling 
of $\mathrm{Ba}$ and TOC has been extensively studied in the Mediterranean Sea; The original extent of sapropels that have undergone partial or complete post-depositional organic matter oxidation ("burn-down") is still recognizable by their sedimentary Ba enrichments (e.g., van Santvoort et al., 1996, 1997; De Lange et al., 2008). In the Black Sea sediments, the decoupling (Fig. 9) is caused by different processes: (1) The $\mathrm{Ba}_{\mathrm{xs}}$ signal has been overprinted extensively by early diagenetic redistribution of $\mathrm{Ba}$ (see also Torres et al., 1996; Brumsack, 2006), and (2) TOC burial in anoxic basins is not only driven by productivity, but also by enhanced TOC preservation (e.g., Arthur and Dean, 1998; Zonneveld et al., 2010). Since biogenic barite formation is associated with TOC degradation in the water column (e.g., Chow and Goldberg, 1960; Bishop, 1988; Bernstein et al., 1992; Ganeshram et al., 2003), the inhibition of aerobic organic matter decay in the Black Sea water column may additionally limit the rate of biogenic barite formation. In fact, Falkner et al. (1993) demonstrated that the establishment of the initial coupling between TOC and $\mathrm{Ba}_{\mathrm{xs}}$ during the deposition of the Black Sea marine units is questionable.

Authigenic and biogenic barite crystals can usually be distinguished by their morphologies and sizes (Torres et al., 1996; Paytan et al., 2002; Paytan and Griffith, 2007). In the surface sediment layer and at 120-122 cmbsf at site 214, typical biogenic barite particles with an ellipsoidal shape were identified (Fig. 10a and b). However, at the same depths and at 150-152 cmbsf, irregular-shaped barites were detected as well (Fig. 10c-f). The differentiation of biogenic and diagenetic barites based on grain size (Table 4) was not possible in the investigated sediments. This stands in contrast to earlier studies (e.g., Paytan et al., 2002; Paytan and Griffith, 2007), where diagenetic barites were identified as "large $(20-700 \mu \mathrm{m})$, flat, tabular-shaped crystals". Since barite crystals with irregular shapes occur in the surface sediments that are likely unaffected by $\mathrm{Ba}$ redistribution, they do not (exclusively) seem to originate from diagenetic precipitation. It must be considered that (1) irregular-shaped barite is supplied from allochthonous (detrital) sources, (2) the shape of biogenic barite formed in an anoxic water column differs from that in oxic ocean basins, or (3) $\mathrm{BaSO}_{4}$ is partly precipitated from anoxic, barite-oversaturated deep waters without any relationship to marine surface productivity, as suggested by Falkner et al. (1993).

Despite these clear indications for the lack of a linear TOC-Ba $\mathrm{x}_{\mathrm{xs}}$ relationship under anoxic conditions, there are numerous studies of anoxic ocean basins (in particular covering OAEs) that apply sedimentary $\mathrm{Ba}$ as a productivity indicator with the assumption that the causal relation between $\mathrm{Ba}$ and TOC is similar to that in oxic ocean basins. Turgeon and Brumsack (2006) stated that the overall high Ba contents in the sediments of the Furlo section in Italy (Cenomanian/Turonian OAE 2) suggest a high paleoproductivity in that area. The authors also discuss the possibility of early diagenesis, but interpret the Ba concentrations as a primary signal based on the dominance of small (tens of microns) barite crystals. The present study, however, shows that the size of barite crystals is not necessarily indicative of their origin, especially in anoxic ocean basins. Similar interpretations of Ba-records that cover OAE2 successions include the Sopeira section in Spain (Drzewiecki and Simo, 1997), the proto-North Atlantic (Kuypers et al., 2002), the Spława section of the Skole Nappe, Poland (Bâk, 2007), and the Demerara Rise (Jiménez Berrocoso et al., 2008). Scopelliti et al. (2004) attempted to use $\mathrm{Ba}_{\mathrm{xs}}$ as a productivity proxy for OAE deposits in Sicily and anticipated that $\mathrm{Ba}_{\mathrm{xs}}$ enrichments in the Bonarelli Level equivalent would reflect high productivities. The authors attributed the unexpected low $\mathrm{Ba}_{\mathrm{xs}}$ contents to a low degree of barite saturation in the oxygen-deficient bottom water. The present study, as well as previous ones (e.g., Falkner et al., 1993; Dean et al., 1997; Hendy, 2010), clearly demonstrates that oxygen depletion alone does not lead to significant dissolution of $\mathrm{BaSO}_{4}$, and that it is rather the presence/absence of sulfate that controls barite (under)saturation in marine settings.

\section{CONCLUSIONS}

The cycling of $\mathrm{Ba}$ and its relationship to TOC in anoxic ocean basin sediments has been studied in two gravity cores from the northwestern Black Sea. Numerical simulations of pore water $\mathrm{Mg}^{2+}$ suggest a gradual (lasting several thousands of years) increase in bottom water salinity after the first intrusion of Mediterranean seawater into the Black Sea. Over the past thousands of years after the initial seawater intrusion, the SMT has migrated into the limnic deposits of Unit III. Diagenetic $\mathrm{Ba}_{\mathrm{xs}}$ enrichments were found at both sites, 755 and 214, at and slightly above the current SMT. Higher sedimentation rates at site 214 have caused the marine sapropel of Unit II to be buried beneath the sulfate-bearing zone, which led to the complete remobilization of $\mathrm{Ba}_{\mathrm{xs}}$ from this TOC-rich horizon. In the Black Sea and comparable settings, in situ degradation of organic matter at shallow depths might exert a strong control on biogeochemical processes and on the overprint of primary sedimentary Ba signals. Accordingly, oxygen-depleted to anoxic bottom water redox conditions indirectly affect the cycling of $\mathrm{Ba}$ in the underlying sediments by favoring TOC preservation and in situ methane production. The investigated Black Sea records provide evidence for a lack of correlation between $\mathrm{Ba}_{\mathrm{xs}}$ and TOC below the SMT, as well as in sections that are unaffected by diagenetic barite redistribution. Within the sulfate-bearing zone, this is probably due to processes taking place in the water column, such as barite precipitation from oversaturated deep waters, lateral transport of Ba-containing minerals, or biogenic barite formation controlled by TOC preservation rather than by productivity alone. The patterns of sedimentary $\mathrm{Ba}_{\mathrm{xs}}$ and TOC distribution in our samples differ from those in the Mediterranean Sea, where oxidized sapropels are identified by productivity-related $\mathrm{Ba}$ enrichments. In the Black Sea, it is the TOC that remains comparably unaffected after burial, while $\mathrm{Ba}_{\mathrm{xs}}$ is diagenetically remobilized at the shallow SMT. The remaining uncertainties related to $\mathrm{Ba}$ precipitation in the water column and the low preservation of the original $\mathrm{Ba}$ signal within the sediments indicate a need for extreme care when interpreting $\mathrm{Ba}_{\mathrm{xs}}$-based 
paleoproductivity records in modern and ancient depositional settings resembling the modern Black Sea.

\section{ACKNOWLEDGMENTS}

We thank the captains, staff members, and scientific parties of cruises P317/2 of RV Poseidon and M72/1 of RV Meteor for their excellent work and collaboration. We are indebted to Brit Kockisch (University of Bremen) and Silvana Pape (MARUM) for TOC measurements and technical assistance. Karsten Enneking (University of Bremen) is thanked for performing the sulfate analyses for core 755. Matthew Jones is highly acknowledged for element analyses on core 755. Birte Oppermann is thanked for support with onboard measurements of methane and Ralf Lendt (both University of Hamburg) for support with isotope analyses. We thank David Fischer (MARUM), Tim Haarmann (University of Bremen), and Ludmila Baumann (AWI) for sample preparation and laboratory support. Martyn Drury and Tilly Bouten are thanked for their help with SEM analyses at Utrecht University and NWO-EUROPROX for financial support. Two anonymous reviewers, Glen Snyder, and Robert C. Aller are highly acknowledged for detailed reviewing of an earlier version of the manuscript. Sandra Arndt and Gerald R. Dickens are thanked for constructive comments. This study was conducted in the framework of the International Graduate College EUROPROX "Proxies in Earth History" funded by the Deutsche Forschungsgemeinschaft (DFG). We acknowledge further financial support from the Helmholtz Association, the University of Hamburg, and the DFG. All data are available in the geological database Pangaea (http:// doi.pangaea.de/10.1594/PANGAEA.779906).

\section{REFERENCES}

Arndt S., Brumsack H.-J. and Wirtz K. W. (2006) Cretaceous black shales as active bioreactors: a biogeochemical model for the deep biosphere encountered during ODP Leg 207 (Demerara Rise). Geochim. Cosmochim. Acta 70, 408-425.

Arndt S., Hetzel A. and Brumsack H.-J. (2009) Evolution of organic matter degradation in Cretaceous black shales inferred from authigenic barite: a reaction-transport model. Geochim. Cosmochim. Acta 73, 2000-2022.

Arthur M. A. and Dean W. E. (1998) Organic-matter production and preservation and evolution of anoxia in the Holocene Black Sea. Paleoceanography 13, 395-411.

Arthur M. A., Dean W. E., Neff E. D., Hay B. J., King J. and Jones G. A. (1994) Varve calibrated records of carbonate and organic carbon accumulation over the last 2000 years in the Black Sea. Global Biogeochem. Cycles 8, 195-217.

Bahr A., Arz H. W., Lamy F. and Wefer G. (2006) Late glacial to Holocene paleoenvironmental evolution of the Black Sea, reconstructed with stable oxygen isotope records obtained on ostracod shells. Earth Planet. Sci. Lett. 241, 863-875.

Bahr A., Lamy F., Arz H., Kuhlmann H. and Wefer G. (2005) Late glacial to Holocene climate and sedimentation history in the NW Black Sea. Mar. Geol. 214, 309-322.

Bahr A., Lamy F., Arz H., Major C., Kwiecien O. and Wefer G. (2008) Abrupt changes of temperature and water chemistry in the late Pleistocene and early Holocene Black Sea. Geochem., Geophys., Geosyst. (G3) 9, Q01004. http://dx.doi.org/10.1029/ $2007 \mathrm{GC} 001683$.

Bạk K. (2007) Organic-rich and manganese sedimentation during the Cenomanian-Turonian boundary event in the Outer Carpathian basins; a new record from the Skole Nappe, Poland. Palaeogeogr. Palaeoclimatol. Palaeoecol. 256, 21-46.
Ballard R. D., Coleman D. F. and Rosenberg G. D. (2000) Further evidence of abrupt Holocene drowning of the Black Sea shelf. Mar. Geol. 170, 253-261.

Barnes R. O. and Goldberg E. D. (1976) Methane production and consumption in anoxic marine sediments. Geology 4, 297-300.

Baturin G. N. (2011) Geochemistry of sapropel in the Black Sea. Geochem. Int. 49, 531-535.

Bernstein R. E., Byrne R. H., Betzer P. R. and Greco A. M. (1992) Morphologies and transformations of celestite in seawater: the role of acantharians in strontium and barium geochemistry. Geochim. Cosmochim. Acta 56, 3273-3279.

Bishop J. K. B. (1988) The barite-opal-organic carbon association in oceanic particulate matter. Nature 332, 341-343.

Blumenberg M., Seifert R., Kasten S., Bahlmann E. and Michaelis W. (2009) Euphotic zone bacterioplankton sources major sedimentary bacteriohopanepolyols in the Holocene Black Sea. Geochim. Cosmochim. Acta 73, 750-766.

Blumenberg M., Seifert R. and Michaelis W. (2007) Aerobic methanotrophy in the oxic-anoxic transition zone of the Black Sea water column. Org. Geochem. 38, 84-91.

Bohrmann G., Ivanov M., Foucher J.-P., Spiess V., Bialas J., Greinert J., Weinrebe W., Abegg F., Aloisi G., Artemov Y., Blinova V., Drews M., Heidersdorf F., Krabbenhöft A., Klaucke I., Krastel S., Leder T., Polikarpov I., Saburova M., Schmale O., Seifert R., Volkonskaya A. and Zillmer M. (2003) Mud volcanoes and gas hydrates in the Black Sea: new data from Dvurechenskii and Odessa mud volcanoes. Geo-Mar. Lett. 23, 239-249.

Borowski W. S., Paull C. K. and Ussler W. (1997) Carbon cycling within the upper methanogenic zone of continental rise sediments; an example from the methane-rich sediments overlying the Blake Ridge gas hydrate deposits. Mar. Chem. 57, 299-311.

Böttcher M. E. and Lepland A. (2000) Biogeochemistry of sulfur in a sediment core from the west-central Baltic Sea: evidence from stable isotopes and pyrite textures. J. Mar. Syst. 25, 299-312.

Boudreau B. P. (1997) Diagenetic Models and Their Implementation: Modeling Transport and Reactions in Aquatic Sediments. Springer, Berlin, Heidelberg, New York, p. 414.

Boudreau B. P. and Ruddick B. R. (1991) On a reactive continuum representation of organic matter diagenesis. Am. J. Sci. 291, 507-538.

Brumsack H.-J. (1986) The inorganic geochemistry of Cretaceous black shales (DSDP Leg 41) in comparison to modern upwelling sediments from the Gulf of California. In North Atlantic Palaeoceanography (eds. C. P. Summerhayes and N. J. Shackleton). Geological Society Special Publication, pp. 447462.

Brumsack H.-J. (1989) Geochemistry of recent TOC-rich sediments from the Gulf of California and the Black Sea. Geol. Rundsch. 78, 851-882.

Brumsack H.-J. (2006) The trace metal content of recent organic carbon-rich sediments: implications for Cretaceous black shale formation. Palaeogeogr. Palaeoclimatol. Palaeoecol. 232, 344 361.

Calvert S. E. (1990) Geochemistry and origin of the Holocene sapropel in the Black Sea. In Facets of Modern Biogeochemistry (eds. V. Ittekkot, S. Kempe, W. Michaelis and A. Spitzy). Springer, Berlin, pp. 328-358.

Chow T. J. and Goldberg E. D. (1960) On the marine geochemistry of barium. Geochim. Cosmochim. Acta 20, 192-198.

Cline J. D. (1969) Spectrophotometric determination of hydrogen sulfide in natural waters. Limnol. Oceanogr. 14, 454-458.

Coffey M., Dehairs F., Collette A., Luther G., Church T. and Jickells T. (1997) The behavior of dissolved $\mathrm{Ba}$ in estuaries. Estuar. Coast. Shelf Sci. 45, 113-121. 
Dale A. W., Regnier P. and Van Cappellen P. (2006) Bioenergetic controls on anaerobic oxidation of methane (AOM) in coastal marine sediments: a theoretical analysis. Am. J. Sci. 306, 246294.

Dale A. W., Regnier P., Knab N. J., Jørgensen B. B. and Van Cappellen P. (2008) Anaerobic oxidation of methane (AOM) in marine sediments from the Skagerrak (Denmark): II. Reactiontransport modeling. Geochim. Cosmochim. Acta 72, 2880-2894.

De Lange G. J. (1983) Geochemical evidence of a massive slide in the southern Norwegian Sea. Nature 305, 420-422.

De Lange G. J. (1992) Shipboard routine and pressure-filtration system for pore-water extraction from suboxic sediments. Mar. Geol. 109, 77-81.

De Lange G. J., Thomson J., Reitz A., Slomp C. P., Principato M. S., Erba E. and Corselli C. (2008) Synchronous basin-wide formation and redox-controlled preservation of a Mediterranean sapropel. Nat. Geosci. 1, 606-610.

Dean W. E., Gardner J. V. and Piper D. Z. (1997) Inorganic geochemical indicators of glacial-interglacial changes in productivity and anoxia on the California continental margin. Geochim. Cosmochim. Acta 61, 4507-4518.

Degens E. T. and Ross D. A. (1972) Chronology of the Black Sea over the last 25,000 years. Chem. Geol. 10, 1-16.

Deuser W. G. (1972) Late-Pleistocene and Holocene history of the Black Sea as indicated by stable isotope studies. J. Geophys. Res. 77, 1071-1077.

Dickens G. R. (2001) Sulfate profiles and barium fronts in sediment on the Blake Ridge: present and past methane fluxes through a large gas hydrate reservoir. Geochim. Cosmochim. Acta 65, 529543.

Dickens G. R., Paull C. K. and Wallace P. J. (1997) Direct measurement of in situ methane quantities in a large gashydrate reservoir. Nature 385, 426-428.

Drzewiecki P. A. and Simo J. A. T. (1997) Carbonate platform drowning and oceanic anoxic events on a mid-Cretaceous carbonate platform, south-central Pyrenees, Spain. J. Sediment. Res. 67, 698-714.

Dymond J. and Collier R. (1996) Particulate barium fluxes and their relationships to biological productivity. Deep Sea Res. Part II 43, 1283-1308.

Dymond J., Suess E. and Lyle M. (1992) Barium in deep-sea sediment: a geochemical proxy for paleoproductivity. Paleoceanography 7, 163-181.

Eagle Gonneea M. and Paytan A. (2006) Phase associations of barium in marine sediments. Mar. Chem. 100, 124-135.

Falkner K. K., Klinkhammer G. P., Bowers T. S., Todd J. F., Lewis B. L., Landing W. M. and Edmond J. M. (1993) The behavior of barium in anoxic marine waters. Geochim. Cosmochim. Acta 57, 537-554.

Falkner K. K., Measures C. I., Herbelin S. E. and Edmond J. M. (1991) The major and minor element geochemistry of Lake Baikal. Limnol. Oceanogr. 36, 413-423.

François R., Honjo S., Manganini S. J. and Ravizza G. E. (1995) Biogenic barium fluxes to the deep sea: implications for paleoproductivity reconstruction. Global Biogeochem. Cycles 9, 289-303.

Froelich P. N., Klinkhammer G. P., Bender M. L., Luedtke N. A., Heath G. R., Cullen D., Dauphin P., Hammond D., Hartman B. and Maynard V. (1979) Early oxidation of organic matter in pelagic sediments of the eastern equatorial Atlantic: suboxic diagenesis. Geochim. Cosmochim. Acta 43, 1075-1090.

Ganeshram R. S., Francois R., Commeau J. and Brown-Leger S. L. (2003) An experimental investigation of barite formation in seawater. Geochim. Cosmochim. Acta 67, 2599-2605.

Gladney E. S. and Roelandts I. (1988) 1987 Compilation of elemental concentration data for USGS, BHVO-1, MAG-1,
QLO-1, RGM-1, SCo-1, SDC-1, SGR-1 and STM-1. Geostand. Newslett. 12, 253-262.

Gleiß R. (2005) Herstellung und Dokumentation eines Laborstandards für Marine Sedimente. Diploma thesis, University of Bremen, Bremen.

Goldberg E. D. and Arrhenius G. O. S. (1958) Chemistry of Pacific pelagic sediments. Geochim. Cosmochim. Acta 13, 153-212.

Grasshoff K., Kremling K. and Ehrhardt M. (1983) Methods of Seawater Analysis. Wiley-VCH, Weinheim, NY, 600 p.

Hanor J. S. and Chan L.-H. (1977) Non-conservative behavior of barium during mixing of Mississippi River and Gulf of Mexico waters. Earth Planet. Sci. Lett. 37, 242-250.

Hay B. J., Arthur M. A., Dean W. E., Neff E. D. and Honjo S. (1991) Sediment deposition in the Late Holocene abyssal Black Sea with climatic and chronological implications. Deep Sea Res. Part II 38(Suppl.), 1237-1254.

Hendy I. L. (2010) Diagenetic behavior of barite in a coastal upwelling setting. Paleoceanography 25, PA4103. http:// dx.doi.org/10.1029/2009PA001890.

Holmkvist L., Kamyshny A., Vogt C., Vamvakopoulos K., Ferdelman T. G. and Jørgensen B. B. (2011) Sulfate reduction below the sulfate-methane transition in Black Sea sediments. Deep-Sea Res. I 58, 493-504.

Jiménez Berrocoso A., MacLeod K. G., Calvert S. E. and Elorza J. (2008) Bottom water anoxia, inoceramid colonization, and benthopelagic coupling during black shale deposition on Demerara Rise (Late Cretaceous western tropical North Atlantic). Paleoceanography 23, PA3212. http://dx.doi.org/ 10.1029/2007PA001545.

Jones G. A. and Gagnon A. R. (1994) Radiocarbon chronology of Black Sea sediments. Deep Sea Res. Part I 41, 531-557.

Jørgensen B. B., Böttcher M. E., Lüschen H., Neretin L. N. and Volkov I. I. (2004) Anaerobic methane oxidation and a deep $\mathrm{H}_{2} \mathrm{~S}$ sink generate isotopically heavy sulfides in Black Sea sediments. Geochim. Cosmochim. Acta 68, 2095-2118.

Jørgensen B. B., Weber A. and Zopfi J. (2001) Sulfate reduction and anaerobic methane oxidation in Black Sea sediments. Deep Sea Res. Part I 48, 2097-2120.

Kasten S., Haese R. R., Zabel M., Rühlemann C. and Schulz H. D. (2001) Barium peaks at glacial terminations in sediments of the equatorial Atlantic Ocean-relicts of deglacial productivity pulses? Chem. Geol. 175, 635-651.

Kasten S., Zabel M., Heuer V. and Hensen C. (2003) Processes and signals of nonsteady-state diagenesis in deep-sea sediments and their pore waters. In The South Atlantic in the Late Quaternary: Reconstruction of Mass Budget and Current Systems (eds. G. Wefer, S. Mulitza and V. Ratmeyer). Springer, Berlin, Heidelberg, New York, pp. 431-459.

Knab N. J., Cragg B. A., Hornibrook E. R. C., Holmkvist L., Pancost R. D., Borowski C., Parkes R. J. and Jørgensen B. B. (2009) Regulation of anaerobic methane oxidation in sediments of the Black Sea. Biogeosciences 6, 1505-1518.

Krüger M., Treude T., Wolters H., Nauhaus K. and Boetius A. (2005) Microbial methane turnover in different marine habitats. Palaeogeogr. Palaeoclimatol. Palaeoecol. 227, 6-17.

Kuypers M. M. M., Pancost R. D., Nijenhuis I. A. and Sinninghe Damsté J. S. (2002) Enhanced productivity led to increased organic carbon burial in the euxinic North Atlantic basin during the late Cenomanian oceanic anoxic event. Paleoceanography 17, 1051.

Lüschen H. (2004) Vergleichende anorganisch-geochemische Untersuchungen an phanerozoischen $\mathrm{C}_{\text {org }}$-reichen Sedimenten: Ein Beitrag zur Charakterisierung ihrer Fazies. Dissertation thesis, Carl von Ossietzky Universität., Oldenburg.

Major C. O., Goldstein S. L., Ryan W. B. F., Lericolais G., Piotrowski A. M. and Hajdas I. (2006) The co-evolution of 
Black Sea level and composition through the last deglaciation and its paleoclimatic significance. Quatern. Sci. Rev. 25, 20312047.

Major C. O., Ryan W., Lericolais G. and Hajdas I. (2002) Constraints on Black Sea outflow to the Sea of Marmara during the last glacial-interglacial transition. Mar. Geol. 190, 19-34.

Marret F., Mudie P., Aksu A. and Hiscott R. N. (2009) A Holocene dinocyst record of a two-step transformation of the Neoeuxinian brackish water lake into the Black Sea. Quatern. Int. 197, 72-86.

Martens C. S. and Klump J. V. (1984) Biogeochemical cycling in an organic-rich coastal marine basin 4: an organic carbon budget for sediments dominated by sulfate reduction and methanogenesis. Geochim. Cosmochim. Acta 48, 1987-2004.

Martínez-Ruiz F., Kastner M., Paytan A., Ortega-Huertas M. and Bernasconi S. M. (2000) Geochemical evidence for enhanced productivity during S1 sapropel deposition in the eastern Mediterranean. Paleoceanography 15, 200-209.

Mogollón J. M., Dale A. W., Fossing H. and Regnier P. (2011) Timescales for the development of methanogenesis and free gas layers in recently-deposited sediments of Arkona Basin (Baltic Sea). Biogeosci. Discuss. 8, 7623-7669.

Morse J. W., Arvidson R. S. and Lüttge A. (2007) Calcium carbonate formation and dissolution. Chem. Rev. 107, 342-381.

Naudts L., Greinert J., Artemov Y., Staelens P., Poort J., Van Rensbergen P. and De Batist M. (2006) Geological and morphological setting of 2778 methane seeps in the Dnepr paleo-delta, northwestern Black Sea. Mar. Geol. 227, 177-199.

Neretin L. N., Böttcher M. E., Jørgensen B. B., Volkov I. I., Lüschen H. and Hilgenfeldt K. (2004) Pyritization processes and greigite formation in the advancing sulfidization front in the upper Pleistocene sediments of the Black Sea. Geochim. Cosmochim. Acta 68, 2081-2093.

Özsoy E. and Ünlüata Ü. (1997) Oceanography of the Black Sea: a review of some recent results. Earth Sci. Rev. 42, 231-272.

Panin N. and Jipa D. (2002) Danube River sediment input and its interaction with the north-western Black Sea. Estuar. Coast. Shelf Sci. 54, 551-562.

Pape T., Bahr A., Rethemeyer J., Kessler J. D., Sahling H., Hinrichs K. U., Klapp S. A., Reeburgh W. S. and Bohrmann G. (2010) Molecular and isotopic partitioning of low-molecular-weight hydrocarbons during migration and gas hydrate precipitation in deposits of a high-flux seepage site. Chem. Geol. 269, 350-363.

Parkhurst D.L. and Appelo C.A.J. (1999) User's guide to PHREEQC (Version 2.0) - A computer program for speciation, batch-reaction, one-dimensional transport, and inverse geochemical calculations, Water-Resources Investigations Report 99-4259, U.S. Geol. Surv., pp. 312.

Paull C. K., Lorenson T. D., Dickens G., Borowski W. S., Ussler, , W. and Kvenvolden K. (2000) Comparisons of in situ and core gas measurements in ODP Leg 164 bore holes. Ann. N. Y. Acad. Sci. 912, 23-31.

Paytan A. and Griffith E. M. (2007) Marine barite: recorder of variations in ocean export productivity. Deep Sea Res. Part II 54, 687-705.

Paytan A., Mearon S., Cobb K. and Kastner M. (2002) Origin of marine barite deposits: $\mathrm{Sr}$ and $\mathrm{S}$ isotope characterization. Geology 30, 747-750.

Pfeifer K., Kasten S., Hensen C. and Schulz H. D. (2001) Reconstruction of primary productivity from the barium contents in surface sediments of the South Atlantic Ocean. Mar. Geol. 177, 13-24.

Pohlman J. W., Bauer J. E., Canuel E. A., Grabowski K. S., Knies D. L., Mitchell C. S., Whiticar M. J. and Coffin R. B. (2009) Methane sources in gas hydrate-bearing cold seeps: evidence from radiocarbon and stable isotopes. Mar. Chem. 115, 102109.

Reeburgh W. S. (1967) An improved interstitial water sampler. Limnol. Oceanogr. 12, 163-165.

Reeburgh W. S. (1976) Methane consumption in Cariaco Trench waters and sediments. Earth Planet. Sci. Lett. 28, 337-344.

Reeburgh W. S., Ward B. B., Whalen S. C., Sandbeck K. A., Kilpatrick K. A. and Kerkhof L. J. (1991) Black Sea methane geochemistry. Deep Sea Res. 38(Suppl. 2), 1189-1210.

Reitz A., Pfeifer K., De Lange G. J. and Klump J. (2004) Biogenic barium and the detrital $\mathrm{Ba} / \mathrm{Al}$ ratio: a comparison of their direct and indirect determination. Mar. Geol. 204, 289-300.

Riedinger N., Kasten S., Gröger J., Franke C. and Pfeifer K. (2006) Active and buried authigenic barite fronts in sediments from the Eastern Cape Basin. Earth Planet. Sci. Lett. 241, 876-887.

Robin E., Rabouille C., Martinez G., Lefevre I., Reyss J. L., van Beek P. and Jeandel C. (2003) Direct barite determination using SEM/EDS-ACC system: implication for constraining barium carriers and barite preservation in marine sediments. Mar. Chem. 82, 289-306.

Rösler H. J. and Lange H. (1972) Geochemical Tables. Elsevier, New York.

Ross D. A. and Degens E. T. (1974) Recent sediments in the Black Sea. In The Black Sea - Geology, Chemistry, and Biology, vol. 20 (eds. D. A. Ross and E. T. Degens). American Association of Petroleum Geologists, Tulsa, pp. 183-199.

Ross D. A., Degens E. T. and MacIlvaine J. (1970) Black Sea: recent sedimentary history. Science 170, 163-165.

Ryan W. B. F., Pitman W. C., Major C. O., Shimkus K., Moskalenko V., Jones G. A., Dimitrov P., Gorür N., Sakinç M. and Yüce H. (1997) An abrupt drowning of the Black Sea shelf. Mar. Geol. 138, 119-126.

Schlüter M. (1990) Zur Frühdiagenese von organischem Kohlenstoff und Opal in Sedimenten des südlichen und östlichen Weddellmeeres: geochemische Analyse und Modellierung Berichte zur Polarforschung. Bremerhaven, 156.

Schulz H. D. (2006) Quantification of early diagenesis: dissolved constituents in pore water and signals in the solid phase. In Marine Geochemistry (eds. H. D. Schulz and M. Zabel). Springer, Berlin, pp. 73-124.

Scopelliti G., Bellanca A., Coccioni R., Luciani V., Neri R., Baudin F., Chiari M. and Marcucci M. (2004) High-resolution geochemical and biotic records of the Tethyan 'Bonarelli Level' (OAE2, latest Cenomanian) from the Calabianca-Guidaloca composite section, northwestern Sicily, Italy. Palaeogeogr. Palaeoclimatol. Palaeoecol. 208, 293-317.

Seeberg-Elverfeldt J., Schlüter M., Feseker T. and Kölling M. (2005) Rhizon sampling of porewaters near the sediment-water interface of aquatic systems. Limnol. Oceanogr. 3, 361-371.

Seifert R., Delling N., Richnow H. H., Kempe S., Hefter J. and Michaelis W. (1999) Ethylene and methane in the upper water column of the subtropical Atlantic. Biogeochemistry 44, 73-91.

Seifert R., Nauhaus K., Blumenberg M., Krüger M. and Michaelis W. (2006) Methane dynamics in a microbial community of the Black Sea traced by stable carbon isotopes in vitro. Org. Geochem. 37, 1411-1419.

Smith E., Hamilton-Taylor J., Davison W., Fullwood N. J. and McGrath M. (2004) The effect of humic substances on barite precipitation-dissolution behaviour in natural and synthetic lake waters. Chem. Geol. 207, 81-89.

Snyder G. T., Dickens G. R. and Castellini D. G. (2007) Labile barite contents and dissolved barium concentrations on Blake Ridge: new perspectives on barium cycling above gas hydrate systems. J. Geochem. Explor. 95, 48-65.

Soulet G., Delaygue G., Vallet-Coulomb C., Böttcher M. E., Sonzogni C., Lericolais G. and Bard E. (2010) Glacial 
hydrologic conditions in the Black Sea reconstructed using geochemical pore water profiles. Earth Planet. Sci. Lett. 296, $57-66$.

Suess E. (1982) Authigenic barite in varved clays: result of marine transgression over freshwater deposits and associated changes in interstitial water chemistry. In The Dynamic Environment of the Ocean Floor (eds. K. A. Fanning and F. T. Manheim). Lexington Books, Lexington, Massachusetts, Toronto, p. 502.

Taylor S. R. (1964) Abundance of chemical elements in the continental crust: a new table. Geochim. Cosmochim. Acta 28, $1273-1285$.

Torres M. E., Brumsack H.-J., Bohrmann G. and Emeis K. C. (1996) Barite fronts in continental margin sediments: a new look at barium remobilization in the zone of sulfate reduction and formation of heavy barites in diagenetic fronts. Chem. Geol. 127, 125-139.

Turgeon S. and Brumsack H.-J. (2006) Anoxic vs dysoxic events reflected in sediment geochemistry during the CenomanianTuronian Boundary Event (Cretaceous) in the Umbria-Marche Basin of central Italy. Chem. Geol. 234, 321-339.

van Os B. J. H., Middelburg J. J. and De Lange G. J. (1991) Possible diagenetic mobilization of barium in sapropelic sediment from the eastern Mediterranean. Mar. Geol. 100, 125-136.

van Santvoort P. J. M., De Lange G. J., Langereis C. G., Dekkers M. J. and Paterne M. (1997) Geochemical and paleomagnetic evidence for the occurrence of "missing" sapropels in eastern Mediterranean sediments. Paleoceanography 12, 773-786.

van Santvoort P. J. M., De Lange G. J., Thomson J., Cussen H., Wilson T. R. S., Krom M. D. and Ströhle K. (1996) Active post-depositional oxidation of the most recent sapropel (S1) in sediments of the eastern Mediterranean Sea. Geochim. Cosmochim. Acta 60, 4007-4024.

von Breymann M. T., Emeis K.-C. and Suess E. (1992) Water depth and diagenetic constraints on the use of barium as a palaeoproductivity indicator. In Upwelling Systems: Evolution since the Early Miocene, vol. 64 (eds. C. P. Summerhayes, W. L. Prell and K. C. Emeis). Geological Society Special Publication, pp. 273-284.

Wall D. and Dale B. (1974) Dinoflagellates in the late Quaternary deep-water sediments of the Black Sea. In The Black SeaGeology, Chemistry and Biology, vol. 20 (eds. E. T. Degens and D. A. Ross). American Association of Petroleum Geologists, Tulsa, pp. 364-380.

Whiticar M. J. (1999) Carbon and hydrogen isotope systematics of bacterial formation and oxidation of methane. Chem. Geol. 161, 291-314.

Yiğiterhan O. and Murray J. W. (2008) Trace metal composition of particulate matter of the Danube River and Turkish rivers draining into the Black Sea. Mar. Chem. 111, 63-76.

Zonneveld K. A. F., Versteegh G. J. M., Kasten S., Eglinton T. I., Emeis K. C., Huguet C., Koch B. P., De Lange G. J., de Leeuw J. W., Middelburg J. J., Mollenhauer G., Prahl F. G., Rethemeyer J. and Wakeham S. G. (2010) Selective preservation of organic matter in marine environments; processes and impact on the sedimentary record. Biogeosciences 7, 483-511.

Associate editor: Robert C. Aller 